\title{
PENERAPAN KHIYAR DALAM JUAL BELI
}

\author{
Oleh : Dewi Sri Indriati
}

\begin{abstract}
Abstrak
Penerapan khiyar dalam jual belt dapat dikonkritisasi atau diaplikasikan, sebab khiyar mempunyai solusi yang jelas dan yang dipakai oleh ekonom modern sekarang dengan beda istilah atau yang dikenal dengan istilah garansi. Hampir semua produksi barang modern menggunakan istilah khiyar (garansii) untuk menarik perhatian konsumen. dan penerapannya memberikan keuntungan yang berlipat. Khiyar (garansi) sangat jeas dan mempunyai arah yang relevan untuk diterapkan. Di dalamnya terkandung prinsip dasar dan tujuan Islam sebagai agama rahmatan li;alami (pemberi) rahmat kepada seluruh alam).

Kata kunci : Khiyar, jual beli
\end{abstract}

\section{PENDAHULUAN}

\section{a. Latar Belakang}

Sejak manusia mengenal hidup bergaul, timbulah suatu masalah yang harus dipecahkan bersama-sama, yaitu bagaiaman setiap manusia memenuhi kebutuhan hidup mereka masing,masing? Karena kebutuhan seseorang tidak mungkin dpat dipenuhi oleh dirinya sendiri. Makin leas pergaulari mereka, bertambha kuatlah ketergantungan antara satu sama lain untuk memenuhi kebutuhan itu. ${ }^{1}$

Perkembangan masyarakat tarnpaknya mengarah kepada asalnya "back to nature" atau "back to basic" katanya. Naisbitt menerjemahkan fenomena ini dalam bukunya Megatrende 2000 yang dituliskannya berdasarkan basil penelitian dan me-makai teori kecenderungan statistik, menyebutkan bahwa masyarakat Ndi tahun 2000 dan seterusnya semakin mengalami peningkatan "religioustity", semangat keagamaan. ${ }^{2}$ Artinya masyarakat akan kembali memberikan perhatian kepada ajaran agamanya. 2002) h. 11

\footnotetext{
${ }^{1}$ Abdullah Zaky al Kaaf, Ekonotni dan Perspektil Islam, (Bandung; Penerbit : $\quad$ Pustaka Setia,
}

\footnotetext{
${ }^{2}$ Sofyan Safri Harahap, Akuniansi Islam,(Cet. I, Jakarta, Penerbit : Bumi Akasara, 1997), h. 1
} 
Islam adalah agarna rahmatan lil alamin dan mengubah pandangan hidup orang perorang, melainkan juga masyarkal dan lembaga-lembaga mempengaruhi seseorang. Meskipun Islam menghargat kebebasan, bukan berarti bahwa kebebasan itu tanpa batas. Berbicara ten-tang kebebasan maka eko-nomi dalam adalah bagian dasar dari kehidupan salah satunya dalah jual beli.'

Jual beli merupakan suatu tradisi yang telah ada serta dikem-bangkan oleh manusia sejak dahulu kala, karena erat hubungannya dengan sisi kehidupan manusia. Manusia secara pribadi mempunyai kebutuhan beraneka ragam yang sedara jelas tidak mungkin dipenuhinya dalam kemandiriannya. Karena tidak ada secara jelas tidak mungkin dipenuhinya dalam kemadiriannya. Karena tidak ada satu manusia pun yang sanggup menjalani kehidupan ini tanpa adanya interaksi dengan sesama manusia lainnya.

Perkataan jual beli terdiri dari dua suku kata yaitu "jual dan beli". Sebenarnya kata jual dan beli mem-puyai arti satu sama lainnya bertolak belakang. Kata jual menunjukan bahwa adanya Islam adalah agama rahmatan hralamm dan mengubah pandangan hidup orang perorang. melainkan juga masyarkat dan lembaga-lembaga mempengaruhi perilaku seseorang. Meskipun Islam menghargai kebebasan, bukan berarti bahwa kebebasan itu tanpa batas. Berbicara tentang kebebasan maka eko-nomi dalam adalah bagian dasar dari kehidupan salah satunya adalah jual beli. ${ }^{3}$

Jual beli merupakan suatu tradisi yang telah ada serta dikembangkan oleh manusia sejak dahulu kala, karena erat hubungannya dengan sisi kehidupan manusia. Manusia secara pribadi mempunyai kebutuhan beraneka ragam yang sedara jelas tidak mungkin dipenuhinya dalam kemandiriannya. Karena tidak ada secara jelas tidak mungkin dipenuhinya dalam kemadiriannya. Karena tidak ada satu manusia pun yang sanggup menjalani kehidupan ini tanpa adanya interaksi dengan sesama manusia lainnya.

Perkataan jual beli terdiri dari dua suku kata yaitu "jual dan beli". Sebenarnya kata jual dan beli mem-puyai arti satu sama lainnya bertolak belakang. Kata jual

${ }^{3}$ Dr. M. Umer Chapra. AI-Duran Menuju Sision Moneier rang Add, (Yogyakarta; Penerbit; PT. Dana Bhakti Prima Yasa, 1997), h,191-192 
menunjukan bahwa adanyaperbuatan menjual, sedangkan beli adalah adanya perbuatan membeli. Dengan dimikian, perkataan jual beli menunjukan bahwa adanya perbuatan menjual, sedangkan beli adalah adanya perbuatan membeli. Dengan demikian perkataan jual beli menunjukan adanya dua perbuatan dalam satu peristiwa hukum jual beli. ${ }^{4}$

Allah mensyi'arkan jual beli sebagai pemberian keluangan dan keluasan dari-Nya untuk hamba-hambaNya, karena semua manusia secara pribadi mempunyai kebutuhan baik berupa sandan, pangan, serta kebutuhankebutuhan hidup lainnya. Kebutuhankebutuhan itu tak pernah terputus dan tak hentinya selama manusia masih hidup, karena tak seorang manusia pun dapat memenuhi hajat hidupnya sendiri oleh karena itu ia dituntut untuk berhubungan dengan yang lainnya. Dalam hubungan ini tak ada satu halpun yang lebih sempurna dari pertukaran, dimana seorang memberikan apa yang ia miliki untuk kemudian ia memperoleh suatu yang berguna dari orang lain sesuai dengan kebutuhan masing-masing. ${ }^{5}$

Faktor-faktor keterbatasan manusia itulah sebgai salah satu motivasi untuk adanya saling tolong menolong, kerja sama, pinjam meminjam, jual beli dan lain-lain. Hal tersebut merupakan sebagian dari aspek ke-hidupan atau tata carapergaulan hidup manusia baik dalam memenuhi kebu-tuhan diri sendiri maupun kernasla-hatan_ umum, Dengan cara demikian cara kehidupan masyarakat menjdai teratur dan terarah serta pertalian antara satu dengan yang lainnya dapat terjalin secara harmonis.

Aplikasi dari jual beli adalah bagaimana tidak ada yang merugikan diantara kedua belah pihak. Didalam silam, mencari keuntungan merupa-kan cerminan pertumbuhan harta. ${ }^{6}$ Maka dengan ini khiyar menjadi criteria yang mendasar dalam pilihan-pilihan jual beli.

Dasar persoalan mu'amalah khususnya pada bidang Khiyar, adalah merupakan satu hal yang dapat membantu manusia disaat hendak melakukan transaksi jual beli dengan pertimbangkan menghindari adanya pembelian abarang yang terdapat cacat didalamnya atau barang-barang yang tidak akan segera dimanfaatkan atau belum

${ }^{4}$ Suharwadi K. Lubis Hukum Ekononti Islam, (Cet. I , Jakarta; Penerbit : Sinar Grafika, 2000), h. 128

${ }^{5}$ Sayyid Sabiq, Figh Sunnah, Jilid XII, Alih Bahasa H. Kamaruddin et. all (Cet. II, Bandung Al Ma'rif, 1988), h. $48-49$

${ }^{6}$ Dr. Husain Syahatah, PokokPokok Pikiran Akuntansi Islam, (Jakarta; Penerbit: Akbar Media Eka Sarana, 2001), h. 143 
dibutuhkan penggunaan-nya, sehingga mengarah pada tindakan mubazir atau mungkin juga adanya perasaan khawatir akan penggunaan barang-barang yang akan dibeli, maka pada saat yang demikian penerapan khiyar dalam jual beli sangat dibutuh-kan, bagi barang-barang yang padanya boleb adak hak khiyar antara penjual dan pembeli.

Dengan demikian diantara kedua belah pihak tidak akan terjadi penyelesaian dikemudian hari atau terhindar dari rasa paksaan, penipuan ataupun kesalahan. Karena sesung-guhnya Islam menghendaki agar jual beli dilaksanakan alas keridhaan semata dan bukan untuk mencari kcuntungan disebelah pihak saja.

Hal mana sesuai dengan hadits Nabi dari Ibnu Umar : Artinya : "Dari Nafi dani That Ungar nu. Bahwasannya Rasultillah saw. bersabda Masing-musing penjual dun pembeli beba.s menentukan jual beli, selagi keduanya belum berpisah atau jual beli dilakukan dengan perjanjian tertentu." Kemudian pada hadits lain jelaskan oleh Nabi Saw :Artinya : "Duri Daud bin Saleh alMadani dari bapaknya berkata bahwa ia mendengan Abu Said Al-Hudriyah berkata bahwa telah bersabda Nabi saw : Sesungguhnya jual beli dilaksanakan dengan keridhaan". ${ }^{7}$

Pada dasarnya svari'at Islam membolehkan adanya penerapan karena tidak lain adalah agar manusia tetap membina hubungan saling kasih mengasihi antara sesama umat manusia serta menghindari rasa dendam, iri dan dengki. Terkadang, seseorang mengadakan pembelian karena hanya melihat aspek luamya saja atau melihat kcincialtan atau kerapihan dari pembungkus banana yang akan dibeli. Apalagi pada masa sekarang ini ditambah dengan iming-iming argmen yang penuh retorika menarik dari penjual, padahal setelah harga yang dibeli lepas dari pembungkusnya maka hanya akan timbul penyesalan disertai rasa iri dan dengki atau bahkan sampai pada pertengkaran atau bahkan percekcokan, karena kenyataan yang ada tidak sesuai dengan keinginan yang diharapkan ataupun mungkin dari contoh yang diperlihatkan kepada pembeli berbeda dengan barang yang diserahkan ketikan berlangsungnya transaksi jual beli.

Dari fenomena yang ada maka syarr at Islam memberi kesempatan bagi setiap orang yang akan melakukan akad jual beli supaya bermawas dirt serta

\footnotetext{
${ }^{7}$ Sunan lbnu Majah Juz II (Indonesia : Maktaba Dahlan, T.Th.), h. 737
} 
mempertimbangkan barang jualannya dengan penuh keiklasan dengan hati yang bersih agar supaya para pembeli tidak menyesal untuk kemudian membatal-kan jual belt tanpa adanya hal-hal yang mendasar secara pasti.

Pada intinya ekonomi Islam dan ekonomi umum yang berbicara lebih spesifik masalah khiyar hampir sama akan tetapi aplikasinya efektif atau tidak. Dan dalam Islam mempunyai dua target yang hakiki yakni dunia dan akherat. ${ }^{8}$

Mengenai pembahasan khiyar dikemukakan oleh ulama Figh dalam permasalahan yang menyangkut per-data. Khususnya transaksi ekonomi, yang menurut mereka bahwa khiyar di syari'atkan atau dibolehkan dalam Islam didasakan pada suatu kebutuh-an yang mendesak dengan memper-timbangkan kemaslahatan masing-masing pihak yang melakukan transaksi. ${ }^{9}$

Mengacu pada pendapat para ulama filth tentang khiyar tersebut, maka jelaslah bahwa didalam syarita Islam khususnya pada persoalan muamalah dalam bidang jual beli terdapat ketentuan-ketetnuan yang saling menguntungkan kedua belah pihak baik penjual maupun pembeli, untuk adanya saling terbuka serta saling meridha dalam transsaksi. Namun dalam hal seperti ini masing sangat belum dipahami oleh masyarakat apalagi dalam penerapannya. Meskipun sistim perdagangan yang berlaku bukan secara Islam namun harus disadari serta setidaknya oleh masyarakat Islam itu sendiri, karena syari'at Islam sifatnya universal.

Jual beli atau perdagangan adalah salah satu kegiatan yang dilaksanakan oleh manusia dalam upaya untuk mendabat penghasilan yang dibutuhkan oleh keluarga menuju kepada suatu kehidupan yang lebih sejahtera khususnya dalam bidang ekonomi.

Islam mengakui semua kegaitan ekonomi manusia yang halal, kegiatan yang sesuai dengan jiwa Islam oleh karena itu Islam menetapkan peraturanpeaturan mengenai kegiatan

\footnotetext{
${ }^{8}$ M. Dawam Rahardjo, Islam dan Transformasi Sosial-Ekonomi, (Cet.I, Yogyakarta; Penerbit: Lembaga StudiA Agama dan Filsafat (LSAF), 1999). h . 12

${ }^{9}$ Dahlan Abdul Aziz, Ensiklopedia Hukum Islam III, (Cet. I, Jakarta : ljtihar Van Hoften, 1996), h. 914
} 
perdagangan yang dengan maksud untuk memastikan bahwa semua hal yang dipraktekan itudilaksanakan secara juju, tulus dan bermanfaat. ${ }^{10}$

Pada prinsipnya khiyar berlaku pada jual beli, karena pada dasar-nya meskipun barangbarang kon-sumsi yang diperjualbelikan itu dapat secara langsung dilihat dengan jelas wujudnya oleh konsumen atau pem-beli, namun masih ada pertimbangan yang harus disepakati bersama oleh kedua belah pihak (penjual dan pembeli). Menurut ulama syafi'iah: melihat barang itu cukup dengan membau/mencium dan merasakannya bila mabi' termasuk barang dapat dicium dan dirasakan seperti madu, saming, buah-buahan dan sesamanya. Mabi' amcam itu syah diperjual belikan dengan cara dilihat, tidak harus dirakan atau dicium. Maka bila mana pembeli menemukan cacat maka dia punyakhiyar meneembalikan mahi Demikian laga sudah dianggap cukup cara jual beli cicngan melihat mufti saja sebagai ganti Mari mengetahui jumlahnya, timbang takarannva atau ukurannya. ${ }^{11}$

Dalam sistem penerapam khiyar bagi penjual disini betul-betul diharapkan supaya bisa terbuka lagi bagi barang dagangannya terhadap konsumen atau pembeli vane membutuhkan, dalam artian penjual harus secara jujur mengatakan tentang kualitas barang dagangannya. Paling tidak to harus bertaka benar, menepati amanah secara jujur. yang oleh Yusuf Qardawi dikstakan bahwa :

a. Berkata benar dalam arti penjual tidak membohong dalam mempromosikan barang:

b. Dan menetapkan harga;

c. Menepati amanah merupakan moral vane mulia dengan maksud mengembalikan apa saja kepada pemiliknya, tidak mengambil sesuatu melebihi haknya dan tidak mengurangi hak orang lain berupa harga maupun upahnya.

d. Jujur selain benar dan memgang amanah, seorang pedagang harus berkata jujur dilandasi keinginan agarorang lain mendapat kebaikan dan kebahagiaan

${ }^{10}$ M.Abdul Mannad, ieori dan Praktiek Ekonomi Islam, (Jogjakarta : Bakti Primayasa 1997), h, 288.

${ }^{11}$ Drs. H. Mohammad Zuhri, Dipl. Tatl, dkk, Mazhab (Bagian Terjentalut Filth Empat lbadah), Jilid III, (Semarang 1994), h. : c v Asy-Syfa'433. 
sebagaimana ia inginkan dengan cara menjelas-kan cacat barang dangangannya yang ia ketahui dan terlihat oleh pernbeli. ${ }^{12}$

B. Rumusan Masalah

Pada dasarnya masih banyak masyarakat utamanya yang beragama Islam belum memahami atau belum meneetahui bahwa didalam ajran Islam ada peraturan tentang tata cara atau etika dalam berjual beli yang sala sate adanya hak berlikir atau khiyar dalam merleruskan atau membatalkan jual beli pada pelaksanaanya harus disepakati bersama.

Untuk itulah pada penelitian ini penulis akan menerangkat serta menguraikan tentang penerapan khiyar dalam jual beli.

Dari perumusan yang ada maka yang menjadi permasalahan pada penelitian ini adlah :

1. Bagaimana system khiyar dalam jual belt?

2. Apakah khiyar berlaku dalam setiap jual beli '?

3. Mungkin saja macam-macam khiyar yang ada?

C. Definisi operasional dan Lingkup pembahasan

Judul penelitian didukung oleh variable yang perlu dibatasi sebagai pegangan dalam kajian lebih lanjut. Variabel yang di maksud adalah Penerapan khiyar (Liam Jual Beli.

Menurut pengertian yang ada karnus makna Penerapan adalah sebagai penggenaan atau perihal mempraktekkan. ${ }^{13}$ Dalam kitab-kitab fiqh Islam pengertian khiyar ialah suatu perjanji-an (perakadan) antara pembeli dan penjual untuk memilih kemungkinan jadi atau tidak jadinya jual beli dalam tempo tertentu (yang ditentukan oleh kedua belah pihak)."14

${ }^{12}$ Dr. Yusuf Qardhawi, Norma dun Etika Ekonomi Islam, Penerjemah Zainal Arifin, (Jakarta : Gema Insan Press, 1977), h. 178

${ }^{13}$ DepDikBud,Kamus Besar Bahasa Indonesia,(Cet.II,Jakarta:balai Pustaka, I 989), h.935

${ }^{14} \mathrm{H}$. M ohammad Anwarfigh Islam, Mu 'amalah,Munakahat, Faraid dan Jinayah (Hukum Perdata dan Pidana Islam beserta kaidah-kaidah Hukumnya), (Bandung:Al-Ma'arif, 1988),h.45 
Makna jual beli secara umum adalah : Artinya : "Menukarkan hark? dengan harta dengan cara teretntu". Berdasarkan pengertian tersebut diatas bahwa Penerapan Khiyar dalam Jual Beli adalah salah satu proses jual beli yang sampai hart ini masih banyak orang yang mengabai-kannya padalah jalan menuju pada kemaslahatan.

Ajaran Islam menghendaki umatnya agar menjadi umat yang kuat, mapan serta tidak lemah dalam menata serta menjalani kehidupan. Karena sesungguhnya Allah swt, menciptakan manusia diatas dunia ini tidak dengan betigu saja, tetapi lebih dari itu Allah memfasilitasinya dengan beragam unsurunsur yang menjadi perlengkapan kebu tuhan manusia yang cara pengelolaannya dapat dilaksanakan oleh manusia melakui perkembangan peradaban manusia yang secara evolutif. Diantara upaya yang dilaksanakannya atau dipraktekkan apakah itu sebagai perilaku maupun dalam bentuk tutur kata, yang dengan demikian akan lebih muda dipahami secara umum.

\section{Tujuan dan Kegunaan Penelitian}

Penelitian ini bertujuan untuk mengangkat serta merumuskan kern-bali sebagian dari peraturan-peraturan yang, ada dalam Islam dalam rangka bermu'amalah khususnya dalam rang-ka melaksanakan transaksi jual belt. Yang dengan demikian umat Islam dapat mensosialisasikan nilai-nilai ajaran Islam secara meluas dalam melaksanakan tindakan ekonomi sesuai dengan tuntunan agamanya.

Adapun kegunaan penelitian ini kiranya dapat menambah wacana pengetahuan penults secara pribadi yang secara kebetulan membina mata kuliah Fiqh Mu'amalah. Demikian juga bagi mahasiswa Jurusah Syar'ah atau Fakultas Syari'ah utamanya Program Study Ekonomi Islam kiranya dapat menjadi rujukan atau sebagai kontribusi pengetahuan yang lebih luas lagi dalam bidang mu'amalah yang pada akhimya dapat diterapkan dalam rangka kehidupan berbangsa dan bernegara.

E. Tujuan Pustaka

Sepanjang pengetahuan penulis, tulisan tentang "Penerapan Khiyar dalam Jual Beli" telah ada akan tetapi untuk rnengkaji penerapan khiyar dengan Al-Qur'an, Hadits Nabi Saw dan Pendapat Para Ulama secara khusus belum ada. 
Diantara tulisanyang banyak menyinggung, masalah ini :

1. Figh Islam, Mu'amalah Munakahat, Faraid dan Jinayah (Hukum Perdata dan Pidana Islam beserta kaidahkaidah Hukum-nya), yang disusun oleh H. Mohamad Anwar, diterbitkan pada tahun 1988 oleh Al-Ma'rif di Bandung. H. Mohamad Anwar dlam pembahasannya tidak di ulas secara mendetail tentang penerap-an khiyar akan tetapi lebih ditonjolkan pada pengertian khiyar sebagai suatu perjanjian (perakadan) antara pembeli dan penjual untuk memilih kemung-kinan jadi atau tidak jadinya jual beli dalam tempo tertentu (yang ditemukan oleh kedua belah pihak). Meskipun harus mengan-tar para pembacanya kepada satu kesimpulan bahwa dari sekian banyak proses ataupun aturan jual beli yang berlaku memungkinan adanya tipu muslihat sedangkan penerapan khiyar masih kurang diterapkan, maka Islam adalah satusatunya jalan yang baik.

2. Terjemah Figh Empat Mazhab, Jilid III, yang disusun oleh Drs. H. Mohammad Zuhri, Dipl. Tafl, diterbitkan pada tahun 1994 oleh cv Asy-Syfa' di Semarang. Drs. H. Mohammad Zuhri, Dipl. Tafl, dalam pembahannya tentang penerapan khiyar lebih kepada penekannya hukum pelaksanaannya yang bersumber pada Al-Qur'an, Hadits Nabi Saw dan pendapat para Ulama sebagai patokan atau pijakan awal penerapan khiyar.

3. Kode etik Dagang menuntut Islam, yang disusun oleh Dr.Hamzah Jacob, diterbitkan pada tahun 1998 oleh Diponegoro di Bandung. Dalam pelaksanaan jual beli inilah dibutuhkan adanya khivar Dr. Hamzah Jacob mentakan hikmah dari pada dibolehkannya khivar dalam Islam adalah untuk kemaslahatan bagi pihak-pihak yang melakukan transaksi itu sendiri, memelihara kerukunan, hubungan baik serta cinta kasih diantara manusia dan macammacam khiyar.

F. Metodologi Penelitian

Bertolak dari tujuan penelitian diatas, maka penelitian ini bersifat deskriptif dan kualitataif. Bersifat deskriptif sebaga penelitian bermaksud mengeksplorasi dan mesosialisasikan penerapan khiyar kepada ma-syarakat, dan bersifat kualitataif sebab data yang dihadapi berupa pernyataan verba. Penelitian ini menggunakan metode :

1. Sumber Penelitian 
Penelitian ini bercorak kepustakaan karena semua sumber datanya berasal dari sumber-sumber tertulis yang bcrakitan langsung dlatau tidak langsung denga materi yang dikaji. Sumnersumber mama yang dipakai dalam kajian ini adalah:

a. Kita-kitab atau buku-buku yang berisikan tentang ilmu kenomi Islam yang mengang-kut dengan penelitian ini.

b. Kitab-kitab atau buku-buku yang membantu dalam analisis tentang bahasa, social kemasyarakatan dan prospek ekonomi kedepan.

c. Kitab-kitab atau buku-buku yang mcmbantu dalam penaelolaan, yang meliputi tentang metodologi, terjemahan dan kitab-kitab atau bukubuku lainnya yang relevan dengan kenyataan.

2. Pengumpulan Data

Metode ini dipergunakan dengan mengumpulkan data kepus-takaan dari beberapa literature yang berhubungan dengan masalah yang diangkat yang pada dasarnya saling berbeda interprestasi dalam pema-haman masing-masing ahli baik secara definisi, teknik pelaksanaan serta pembagiannya, kemudian penu-lis rnengkaji serta menelaah data-data yang ada.

3. Metode Pendekatan

Metode pendekatan yang di pakai oleh penulis adalah :

a. Pendekatan Kultural, yaitu dengan mempelajari hasil-hasil kajian para ulama kemudian penulis menghubunakan dengan kondisi kekinian.

b. Pendekatan fenomenal yaitu dengan melibat dinamika ataufenomena masyarakat Isam pada umumnya baik menurut aspek sosiologi maupun antropologi yang diinduksi dan realitas sosial.

c. Pendekatan normative moralis, yaitu pendekatan melalui ketentuan-ketentuan atau peraturan-peraturan yang disepakati

4. Metode Pengolahan data

Dari data yano terkumpul di seleksi. kemudian diadakan pengklasitikasian secara tertentu berdasarkan kateaori-kategorinya kemudian anrara data itu dikorelasikan 
dengan merujuk pada tujuan penelitian. Pada akhirnya dart klasifikasi data yang telah diturnuskan melalui kerangka pemikiran penulis kemudian dapat ditarik kesimpulan.

Tahapan terakhir dari laporan penelitina ini adalah menggunakan tata cara yang lazim digunakan dalam penelitian.

\section{G. Out Line Penelitian}

Langkah pertama adalah membahas pengertian khiyar secara ethimologi (bahasa) dan terminologi (istilah) serta syarat khiyar. Ini untuk mengetahui lebih jelas tentang khiyar agar tidak terjadi kesalah pahaman dalam mengartikan khiyar.

Langkah kedua adalah membahas macam-macam khiyar dalam bahasan mi akan ditemukan bahwa khiyar mempunyai jalan yang menghindarkan dari berbagai tipu muslihat.

Langkah ketiga adalah membahas khiyar yang terdapat dalam nash al-Qur'an. Fladits Nabi Saw. Ijma' dan pendapat para Ulama. Pada langkah ini akan dijaki khiyar sebagai dasar hukum yang akan memperjelas posisi khiyar dalam jual beli.

Langkah keempat adalah membahas obyek dan kiriteria penerapan khiyar dalam jual beli serta analisis penerapannya. Disini akan terlihat bahwa khiyar diperolehkan dalam proses jual belt dalam Islam disebabkan mempunyai outologi dan aksiologi yang sangat dianjurkan bahkan menutup urang gerak tipu muslihat dan penyeleisaian di kemudian hart. Outologi adalah membawa ajaran yang rasional sedangkan aksiologi adalah membawa ajaran universal.

Langkah kelima adalah mengemukakan kesimpulan dari seluruh rangkaian bahasa dan sekaligus merumuskan jawaban permasalahan. Disini akan terjawab bagaiama konsep penearpan khiyar dalam jual beli.

\section{BEBERAPA PERSOALAN YANG BERKENAAN DENGAN KHIYAR}

A. Pengertian Khiyar

Jual beli merupakan salah satu bentuk dari budaya dulu kala untukmelakukan pertukaran kebutuhan. Maka dengan melakukan jual beli proses hak milik secara mutlak akan terjadi dengan dilakukannya (akad) transaksi. Jual beli tidak sah dilakukan 
kecuali orang yang memilih tasharruf (pembelanjaan) secara mutlak, bukan orang yang terlarang, membelanjakan hartanya dan wajib melakukan, ijab qabul. ${ }^{15}$

Salah satu factor yang menjadi dasar jual beli adalah kejujurun dun kebenarcin Kejujuran dan kebenaran merupakan nilai yang terpenting sehubungan dengan hal tersebut, penipuan, sikap rnengeksploitasi orang lain yang tidak bersalah dan orang yang jahil atau membuat pernyataan palsu merupakan perbuatan yang dilarang. Iklan palsu dan sikap penipuan para $\mathrm{p}$ enjual merupakan contoh yang tidak baik. ${ }^{16}$

Setiap orang tidak sama kepandaiannya, kealiannya, keinginannya, kesenangannya, kebenciannya dan sebagainya. Maka oleh karena itu setiap manusia memerlukan hubungan dan pergaulan antara satu dengan yang lainnya, agarmereka mencapai kebutuhannya. Disini terletak proses berfikir bebas untuk memilih dengan khlas. Dengan demikian, dalam jual beli Islam kita kenal dengan "khiyar".

Al-Khiyar ialah mencari kebaikan dari dua perkara; melangsungkan atau mebatalkan. ${ }^{17}$ atau proses melakukan pcmilihan terhadap sesuatu. Klayar menurut etimologi (bahasa) al-khiyar artinya pilihan. pembahasan al-khiyar dikemukakan oleh para ulama figh dalam permasalahan yang menyangkut transkasi dalam bidang perdata khususnya transaksi ekonomi. sebgai salah satu hak bagi kedua belah pihak yang meakukan transaksi (akad) ketika terjadi beberapa persoalan dalam transaksi yang dimaksud. ${ }^{18}$ secara terminology para ulama figh mendefiniskan al-Khiyar dengan ${ }^{19}$. Hak pilih salah satu atau kedua belah pihak yang melaksanakan transaksi untuk melangsungkan atau mebatalkan transaksi yang disepakati sesuai dengan kondisi masingmasing pihak yang melakukan transaksi.

\footnotetext{
${ }^{15}$ Hafid Abdullah, KWIC/ Figh Syafi 'I, (Cet. I, Semarang; Penerbit : cv. Asy — Syifa', 1992), h. 126. 1991), h. 58

${ }^{16}$ Muhammad Nejatullah Siddiqi, Kegialan Ekonomi dan Islam, (Jakarta, penerbit : Bumi Aksara,

${ }^{17}$ Sayyid Sabiq, Figh Sunnah. Jur. XII, (Cet., Bandung ; Penerbit: PT al-Ma'rif, 1987), h. 106. 2000)h. 129

18 Dr. H. Nasrun Haroen, MA., Figh Mu 'amalah, (Cet I, Jakarta; Penerbit Gaya Media Pratama,
}

${ }^{19}$ Wahbah Az-Zuhaili, al-Figh al-Islami wa Adilatuhur, Jilid IV, (Beirut, Dar al-Fikr), h. 519. 
Sedangkan ada yang berpendapat secara terminology (istilah fiqh) berarti hakpilih bagi salah satu atau kedua belah pihak yang melaksanakan transaksi dengan ikhlas tanpa ada paksaan. ${ }^{20}$ Khiyaiini dilaksanakan dengan maksud untuk menjami kebebasan berfikir antara penjual dan pembeli.

Hak khiyar ditetapkan syari'at ilsam bagi orang-orang yang melakukan transaksi perdata agar tidak dirugikan dalam transaksi yang mereka lakukan, sehingga kemaslahatan dituju didalam suatu transaksi tercapai dengan sebaiknbaiknya. Status khiyar menurut ulama figh, adalah disyari'atkan atau dibolehkan karena suatu keperluan yang mendesak dalam mempertimbangkan kernaslahatan masing-masingpihak yang melakukan transaksi. ${ }^{21}$

Khiyar dapat pula dibagi menjadi dua : khiyar secara sempit adlah "pilihan" sedangkan khiyar secara umum adalah pilihan bebas dengan ikhlas tanpa ada paksaan.

Akan tetapi khiyar atau kebebasan menurut seorang ekonom barat Nozick (1974) tidak memadainya perilaku pementingan diri juga dapat menjadi soal serius bagi pendekatan etika yang menekankan kebebasan. Orang itu bebas mengejar kepentingandiri (yang tunduk pada kendala-kendala itu) tanpa halangan atau rintangan. ${ }^{22}$

Dengan melihat berbagai kemajuan pangsa pasar yang sangal pesat maka para penjual melakukan promosipromosi untuk memperkenalkan barang yang dijual kepada para konsumen. Salah satu promosi dan paling banyak diminati oleh konsumen yakni garansi. Garansi merupakan pembelian barang dengan tangguhan waktu yang ditentukan oleh penjua. Ini dimaksudkan untuk menjaga apabila dalam pembelian oleh para konsumen atau pembeli mengalami cacat ataupun mengalami kerusakan dalam Nvaktu garansi yang telah ditentukan oleh penjual:. Pada dasarnya jual beli pasti mengikat setelah memenuhi syaratsyaratnva. Akan tetapi terkadang menyimpang dari ketentuan

${ }^{20}$ Dahlan Abdul aziz, Ensiklopedia Hukum Islam III, (Cet. 1; Jakarta : Ittihad Van Hoften, 1996), h. 914

${ }^{21}$ Ibid. h. 520

${ }^{22}$ Amartya Sen, Masih Adakah Harapan Bagi Kaum Miskin?, (Bandung, Penerbit : Mizan, 1998), h. 43-44. 
dasar dalam beberapa persoalan khiyar. Karena didalam khivar terkandung hikmah yang besar, yaitu, adanya kemaslahatan bagi kedua belah pihak yang melakukan jual beli. ${ }^{23}$

Sesungguhnya syari'at Islam sangat komplit dan kohem melihat permasalahan ini, dimaksudkan untuk mengikat tali silatruahmi antar sesama umat manusia demi menghindari dari si fat dengki, munafik dan dendam.

\section{B. Syarat Khiyar}

Bertolak dari berbagai permasalahan yang ada maka syari'at Islam memberikan kesempatan kepada orang melakukan jual beli agar waspadil terhadap dirinya dan mempertimbangkan barang dagangannya dengan had yang bersih agar dikemudian hari tidak terjadi penyesalan. dengan membatasinya yang berbentuk syaratsyarat menjamin tetapnya akad, sehingaa memberikan peluang mengurungkan atau membatalkan akad tanpa ada sebab yang ielas. Dengan melihat beuitu kompleksnya permasalahan ini maka menurut Asy-Syad'iyah "Sesungguhnya khiyar dalam jual beliitu tidak sah kecuali dengan dua perkara" yakni :

1. Hendaknya penjual dan pembeli sepakat dengan cara khusus, yang akan anda ketahui.

2. Hendaknya pada barana dagangan terdapat cacat yang memperkenankan dikembalikan. ${ }^{24}$

Sebagai salah satu aspek dari hukum- universal keadilan social merupakan sendi system ekonomi Islam sebgaimana terdapat al-Qur'an dan Hadits Nabi saw serta implikasinya adalah menjamin kemerdekaan bagi individu dalam menghadapi penyalahgunaan kekuasaan ekonomi oleh orangorang yang memilikinya. ${ }^{25} \mathrm{Maka}$ dengan ini penul is memberi kan penj el asan beberapa macam khiyar.

C. Macam-macam Khiyar

${ }^{23}$ Drs. H. Mohammad Zuhri Dipl. Tafl, dkk, Tertemah Fiqh Empat kfazhab (Raglan lbadah) Jilid III, (Semarang; Penerbit : cv. AsySyafi', 1994), h. 350

${ }^{24}$ Ibid., h. 351

${ }^{25}$ Syed Nawab Haider Naqvi, Etika dan Ihnu Ekonond Suaiu Sinielis islanii, (Cet, I, Bandung; Penerbit: Mizan, 1993), h. 126 
Salah satu prinsip dalam jual beli menurut syarita Islam ialah adanya hak kedua belha pihak yang melakukan transaksi. Hak tersebut dinamakan khiyar. Adakalanya seorang terlanjur membeli barang, sekiranya hak khiyar tidak ada, akan menimblukan penyelesaiam salah satu pihak dan dapat menjurus menjadi kemarahan, kedengkian, dendam, pertentangan dan berbagai akses yang buruk lainnya yang diperingaktkan oleh agama untuk dihindari.

Oleh karena itu, syari'at bertujuan melindungi manusia dari pada keburukankeburukan itu, maka syariat menetapkan adanya hak khiyar dalam rangka tegaknya keselamatan, kerukunan, dan keharmonisan dalam hubungan antar manusia. Dalam hubunan ini ada beberapa macam khiyar dalam rangka tegaknya keselamatan, kerukunan, dan keharmonisan dalam hubungan antar manusia.

Dalam hubungan ini ada beberapa macam khiyar dalam Fiqh Islam yakni :

a. Khiyar ar-Ru'yah, yaitu hak pilih bagi pembeli untuk menyatakan berlaku atau batalnya jual beli yang dilakukan terhadap suatu obyek yang belum dilihatnya ektika akad berlangsung ${ }^{26}$ Sebelum akad terjadi, baik pembeli ataupun penjual belum terikat pada bebas menentukan (memilih), apakah transaksi itu dilangsungkan atau diurungkan (membatalkan). Dapat juga dikatakan bahwa khiyar ru lvah itu, masa memperhatikan keadaan barang menimbang-nimbang dan berfikir sebelum mengambil keputusan melakukan transaksi atau akad.

Mengingat kemungkinan timbulnya akibat-akibat buruk jika dilakukan transaksi bagi roang yang gaib (tidak dilihat), maka segolongan fuqaha mensyaratkan dilihatnya (diru'yahnya) barang bagi sahnya jual beli.

Namun menurut kenyataan banyak pula barang tidak mungkin diketahui kualitasnya secara langsung, yang apabila dibukan menimbulkan kerusakan barang. Misalnya makanan kaleng yang tidak terlihat secara jelas makanan yang ada dialamnya dan hanya melihat daftar ataupun jangka waktu yang berlaku. Dalam keadaan tersebut boleh tidak diru'yah secara langsung dengan catatan ada hak khiyar apabila ternyata ada kerusakan atau kualitasnya buruk. Dalam hubungannya dengan itu ada riwayat dan Abu Hurairah bahwa Nabi Saw bersabda : Barang siapa membeli sesuatu yang belum

\footnotetext{
${ }^{26}$ Lihat : Dahlam Abdul Aziz, op.cit., h.917.
} 
dilihatnya, maka ada hak khiyar baginya apabila dia telah melihatnya. (HR. Daruqthni dan al-Baihaqyh).

Sungguhpun hadits tersebut dha' if karena dalam sanadnya terdapat Umar bin Ibrahim al-Kurdi, tetapi maknanya terpakai arena logis dan sejalan dengan prinsip khiyar itu sendiri.

Dari keterangan ini dapat difahami bahwa titik berat hak khivar itu berada pada pihak pembeli. Tetapi perdagangan itn secara barter. tentulah kedua belah pihak perlu khiyar ru'yah. Hikmah khivur ru 'yah ini dapat dipahami, yakni untuk menghindari penipuan. kesamaran dan penyesalan yang mengundang sengketa bagi kedua belah pihak.

Sebaliknya barang yang diru'yah dengan teliti dan tuntas sebelum di beli, atau adanya hak khiyar, setelah barang diteliti ternyata kualitasnya menyalahi pernyataan penjual, tentunya membelinyapun akan diurungkan. Prinsip ini bertujuan membina kerukunan dan keharmonisan dalam bermu'amalah. Dan maslahat itulah yang menjadi tujuan syari'at Islam.

b. Khiyar Majleis yaitu hak pilih untuk kedua belah pihak yang berakad untuk membatalkan akad selama keduanya masih berada dalam majelis akad dan beli berpisah badan/tempat. Karena hak membatalkan transaksi masih tetap ada selama kedua belah pihak masih berada di majelis itu. Ibnu Umar memberikan bahwa Nabi Saw : Sesuagguhnya kedua belah pihak yang berjual boleh khiyar dalam jual beli selama keduanya belum berpisah). (HR.Bukhari).

Amr bin Syu'aib menerima berita dari gurunya melakui bapaknya bahwa Nabi saw. bersabda : Penjual dan pembeli berhak khiyar hingga keduanya berpisah, kecuali jual dengan syarat dan tidak boleh icr berpisah dari padanya lantaran khawatir ia minta dihatalkan. (HR. Daraquthni dan lain-lain).

Baihaqi merwiayatkan bahwa Abdullah bin Umar berkata : "Saya telah menjual kepada Amirul Mu'minin Utsman ra. Harta di Wadi dengan hartan di Khaibar. Ketika kami telah berjual beli, saya mundur ke belakang hingga saya keluar dari rumahnya lantaran saya kawatir ia emmbatalkan jual belinya, sebab menurut Sunnah, kedua belah pihak yang berjual beli berhak khiyar sampai keduanya berpisah. 
Dalil-dalil tersebut menetapkan adanya hak khiyar majelis. Dan prinsip itulah yang menjadi pegangan jumhur ulama dari pada sahabat dan tabi'in termasuk Imam Syafi'I dan Ahmad. Yang menyalahi pendapat tersebut ialah Imam malik dan Abu Hanifah dimana tidak mengakuinya adanya khiyar majelis. Alasan fugha yang tidak menerima khiyar majelis itu ialah karena khiyar yang demikian $\mathrm{ti}$ itu adalah kesamaran, sedangkan pada dasarnya jual beli adalah kepastian.

Pengikut-pengikut Imam Malik berpendapat bahwa pengertian khiyarialah memilih barang yang dijual. Tetapi oleh karena kuatnya dalil yang menunjukan adanya khiyar majelis, dan bukan dari ijtihad (ra'yu) melainkan kepastian nash yang terang, maka kukuhlah kedudukan hukum khiyar majelis tersebut.

Dengan memperhatikan dalil-dalil itu, maka hak khiyar itu dengan sendirinya menjadi gugur, apabila kedua belah pihak telah berpisah dari majelis akad.

c. Khiyar as-Syart, (syarat) yaitu hak pilih yang ditetapkan bagi salah satu pihak yang berakad atau keduanya atau bagi orang lain untuk meneruskan atau membatalkan jual beli selama masih dalam tenggang waktu yang ditetapkan. Adanya khiyar syarat menurut syari'at Islam, diterangkan dalam berbagai hadis. Menurut riwayat Bukhari dan Muslim, Ibnu Umar memberitakan bahwa ada seorang laki-laki melaporkan kepada Nabi Saw bahwa is ditipu orang dalam jual beli. Maka bersabdalah Nabi saw. "Jika kamu berjual beli. maka katakanlah :-Tidak (jangan) ada tipuan, kemudian engkau mempunvai hak khiyar selama tiga malam Dari Ibnu Umar diberitakan Dua orang yang her lual hell boleh berkhiyar selatna duanru belum berpisah atau salah seorang diantaranya mengadakan kepada rekannya. Khiyarlah dan ada juga beliau bersabda "Atau dalam jual beli itu ada khiyar." (HR. Bukhari).

Jumhur Fuqha sepakat mengakui kebolehan mengadakan syarat khiyar dalam jual beli, tetapi mereka berselisih faham dalam menetapkan jangka waktunya.

Abu hanifah dan Syafi'I menetapkan jangka waktu dalam berbagai kategori : untuk barang yang tidak bergerak seperti tanah dan pohon selama 36 sampai 38 hari. Kesempatan khiyar untuk barang-barang dagangan biasa, dari tiga sampai lima hari, dan kalu lebih daripada itu rusaklah akad jual beli. Untuk bintang, masa khiyarnya juga dari tiga sampai lima hari, sedangkan untuk hamba sahaya tenggang waktunya dari delapan sampai sepuluh hari. Adapun menurut imam Ahmad, yaiu penting ialah 
jangka waktu itu harus jelas (ma'lum) dan tidak ada pembatasan. Boleh saja menentukan sebulan dan seetahun. Yang tidak sah ialah apabila tenggang waktu itu tidak dinyatakan dengan terang (majhul).

Memperhatikan nash dan pandangan para fugaha dapat diambil kesimpulan tentang batas waktu khiyar syarat ialah tergantung kesepakatan dari dua belah pihak. Selama waktu khiyar syarat itu berlangsung, kedua belah pihak terikat dengan syarat, maka seyogyanya jangka waktu ditentukan itu tidak tiga hari atau tiga malam, sebagaimana disebutkan dalam hadits.

d. Khiyaral 'Aib (cacat) yaitu hak untuk membatalkan atau melangsungkan jual beli bagi kedua belah pihak yang berakad apabila terdapat suatu cacat pada obyek yang diperjual belikan. Dari Hakim bin Hizam, Nabi Saw. pernah menerangkan : dan jika keduanya benar dan menvatakan keadaan barang, keduanya diberikan keberkahan dalam jual belinva. Dan kale kecluanva menyembttnvikan clan berdusta, dihapus keberkahan pia! belt. (HR. Bukhari).

Adakanya seseorang membeli barang yang cacatnya baru diketahui bbeberapa waktu kemudian setelah akad jual bei itu berlangsung. Apabila terjadi hal semacam itu, maka pihak pembeli berhak mengemba likan barang dan menerima kembali Liangnya dari pihak penjual.

Itulah yang disebut "khiyar'aib", yakni hak mengernbahkan barang yang bercacat dan sudah diterangkan oleh pihak penjual sebelum transaksi terjadi, lalu pembeli ridha, maka asudah tentu hak khiyar aib itu sudah hapus. Tetapi apabila barang yang cacatnya baru diketahui setelah akad jual beli terjadi. Maka ada tiga alternatif bagi pembeli:

Pertama, apabila pembeli ridha, maka barang itu terus ditangan danjual beli itu dipandang sah. Kedua, membatalkan sama sekali akad jual beli segera setelah cacat itu diketahui. Ketiga, menuntut ganti rugi dari pihak penjual, seimbang denan cacat barang atau menerima potongan harga barang sebanding dengan cacatnya.

Ibnul Mundzir menerangkan : hasan, Syaraih, Abdullah bin Hasan. Ibnu Abi Laila, Tsauri dan ahli-ahli ra'yu, sepakat bahwa apabila seseorang membeli barang yang diketahui ada cacatnya, lalu dia jual lagi. maka khiyarnya telah hapus. 
Pendapat ini jua diperangi oleh as-Syafi'I (Fiqhus-Sunnah XII: 131). Ada dua kemungkinan terlanjurnya pembelian barang yang bercacat: Pertama karena memang pihak si penjual itu sendiri tidak mengetahui bahwa barang jualannya cacat, karena isinya tersembunyi dalam kulitatau bungkusan yang rapat. Kedua, karena ada unsur kesenjangan menipu dengan menyembunyikan cacat barang. Pada dasarnya kedua hal itu tetap memberikan hak khiyar kepada pihak pembeli.

Adanya hak khiyar karea aib, diterangkan oleh sejumlah Hadis Nabi Saw, antara lain yang meriwayatkan oleh Imam Syafi'I dan Ashabus Sunan : Seseorang membeli budak di zaman Rasulullah saw. dan keadaan budak itu Masya Allah (bercacat). Kemudian is kembalikan budak itu karena aib (cacat) yang ada padanya. (Rupanya orang itu mengadukan kepada Rasulullah). Maka Rasulullah saw. memberikan keputusan hukum untuk mengembal-ikannya karena aib (cacat) itu. Orang yang dikenali putusan itu berkata "Ya Rasulullah dia telah memperkerjakannya!" Rasulullah menjawab : "itu adalah resikojaminan".

Dalam pada itu hadits riwayat Bukhari menerangkan adanya seorang lakilaki yang melaporkan kepada Rasulullah bahwa dia ditipu dalam jual beli, kemudian nabi menyatakan kepadany keterangan ini mkenunjukan adanya hak khiyar aib. Dalam suatu riwayat melalui jalan Yunus bin Bushair dan Abdil a'la suatu ditandaskan : "... Kemudian engkau khiyar setiap barang yang engkau beli dalam masa tiga malam. jika engkau suka .peganglah ba-rang-nya dan jika engkau tidak suka maka kembalikanlah-. Sebaliknya pihak penjualpun kadangkadang merasa tertipu karena kelicikan pembeli, menjemput dan memborong barang sebelum masuk pasar dimana penjual tidak mengetahui harga pasaran. Dalam keadaan seperti itu, pihak penjual mempunyai hal khiyar berdasarkan hadits Abi Hurairah, dimana Nabi saw. bersabda : Janganlah kalian rnenghadang barang yang dibawa (dari luar kota). Barang siapa menghadang dan membeli dari padanya, inaka apabila penjual sampai ke pasar, baginya ada hak khiyar. (HR. Muslim).

Garis-garis syara' ini menunjukkan hikmah ajaran Islam yang luhur yang tidak menghendaki adanya pihak yang teraniaya dalam mu'amalah. Mu' amalah dikehendaki berlangsung tertib, lancar dan harmonis serta medatanglah kebaikan bagi semua pihak. 
e. Khiyar at-Ta'yim, yaitu hak pilih bagt pembeh dalam menentukan barang yang berbeda kualitas dalam jual belt. Misalnya dalam pembeliannya komputer ada yang berkualitas dan -ada- yam rakitan (tiruan),akan tetapi pembeli tidak mengetahTh secara pasti mana komputer yang berkualitas atau tiruan dan jenis yang sangat sulit dibedakan.Untuk menentukan pilihan tersebut ia memerlukan bantuan dart ahli komputer. Khiyar seperti ini menurut ulama Mazhab Hanafi,adalah boleh. Alasannya produk sejenis yang berbeda kualitas sangat banyak dan tidak diketahui secara pasti oleh pembeli, sehingga ia memerlukan bantuan seorang ah1i.Khiyar ini ditujukan agar pembeli tidak tertipu dan sesuai dengan kebutuhannya.

Akan tetapi jumhur Ulama Fiqh tiak membolehkan khiyar ta'yin yang dikemukakan ulama mazhab Hanafi ini. Alasan mereka, dalam akad jual beli ada kenteuan bahwa barang yang diperdagangkan harus jelas baik kualitas dan kuantitasnya. Menurut mereka dalam persoalan khiyar ta'yin bahwa identitas barang yang akan dibeli belum jelas. Oleh sebab itu, ia termasuk kedalam jual beli alina'dum (tidak jelas idtentiasnya yang dilarang syara'.

Ulama mazha Hanafi yang membolehkan khiyar ta'yin mengemu-kakan tiga syarat untuk sahnya khiyar ini yaitu (a) pilihan dilakukan terhadap banana sejenis yang berbeda kualitas clan siFatnya; (b) barang itu berbeda sialat dan nilainya: dan (c) dan tenggang waktu untuk khiyar ta'yin itu hams ditentukan, yaitu menurut Imam Abu Hanifah tidak lebih dart tiga hart. Khyiyar ta'yin menurut ulama mazhab Hanafi, hanya berlaku dalam transaksi yang bersifat pemindahan hak milik yang berupa materi dan mengikat gai kedua helh pihak, seperti jual beli. ${ }^{27}$

Dar' penjelasan secara spesifik pada etimologi, terminology, syarat dan macammacam khyiar maka penganjuran ataupun pembolehan untuk menghindari penyalahgunaan jual beli dan penipuan yang dapat mendatangkan perseslisihan.

\section{DASAR HUKUM DAN PENDAPAT PARA ULAMA}

A. Al-Qur'an dan Hadits Nabi Saw

${ }^{27}$ Lihat : Dahlan Abdul Azis, op.cit., h.916 
Al-Qur'an tidak bisa dipandang sebagai buku biasa. Memang, nama lain alQur'an adalah Al-Kitab yang artinya adalah The Book atau buku. Makna Al-Quran sendiri adalah bacaan. ${ }^{28}$ Dan menjadi sebagian dasar hukum yang, paling mendasar diatas segala hukum.

Dasar hukum dari sesuatu akan mengakibatkan legalitas social dan is tidak akan menjadi konsep pemikrian yang ilmiah tanpa ada objektivikasi hukum.

Sebagaimana telah penults terangkah khiyar secara etimologi (bahasa) dan terminology (istilah) serta macammacam khiyar, ini dimaksudkan untuk menghindari kesalahpahaman, maka akan lebih komprehensif kiranya apabila diterangkan juga dasar hukum berlakunya khiyar dalam jual beli.

Dibawah ini adalah beberapa nash yang menerangkan tentang landasan hukum jual belt dan menjadi dasar Hadits Nabi saw yang menafsirkan penerapan khiyar serta berpegang pada prinsip Islam :

Dan jangalah kamu mencampur adukkan yang hak dan yang basil dan janganlah kamu menvembunyikan yang hak itu, sedang kamu mengetahui. ${ }^{29}$ QS Al-Baqarah (2) : 42

Dan belanjakan (harta bendamu) dijalan Allah, dan jangan kamu menja-tuhkan diritnu sendiri kedalam kebinasa-an, dan berbuat baiklah, karena sesungguhnya Allah menyukai orang-orang yang berbuat baik ${ }^{30}$. QS Al-Baqarah (2): 188

Hai orang-orang yang beriman, hendaklah kamu jadi orang-orang yang selalu menegakkan (kebenaran) karena Allah menjadi saksi dengan adil. ${ }^{31}$ QS Al -Maidah (5) : 8

Tuhanku hanya mengharamkan perbuatan keji, bvaik yang nampak ataupun yang tersetnbunyi, danperbuatan dosa, melanggar hak tnanusia tanpa alasan yang benar, (mengharamkan) mempersekutukan Allah dengan sesuatu yang Allah tidak menurunkah

${ }^{28}$ Mochtar Naim, Kompendium Hinzpunan Ayal-Ayat AI-Qur'an yang berkaaan dengan Ekononn, (Kata Pengantar oleh Dawam Rahardjo), (Jakarta,; Penerbit cv Hasanah, 2001), h xiii

\footnotetext{
${ }^{29} \mathrm{Ibid}$, h. 5

${ }^{30}$ Ibid, h. 9.

${ }^{31} \mathrm{Ibid}$, h. 42
} 
hujjah untuk itu dan (mengharamkan) tnengadaadakan terhadap Allah apa yang kamu tidak ketahui. ${ }^{32}$ QS Al -A'raf (7) : 33

(Muhammad) berkata : Ya Tuhanku, berilah keputusan dengan adil dan Tuhan kami ialah Tuhan yang Maha Pemurah lagi yang dimohon pertolongan-Nya terhadap ap yang kamu katakan. ${ }^{33}$ QS A1-Anbiya (21) : 112

Allah nada melarang Linn( untuk berbuat balk dun berlaku udll ferhadap orang-orang rang nada memerangimu arena agama clan tidak mengusir kamu dari negerimu. Sesungguhnya Allah menyukai heriaku orang-orang yang berlaku adil. ${ }^{34} \mathrm{QS} \mathrm{Al}$ Mumtahanah (60):8

Dengan melihat nash al-Quran maka jelaslah penerapan khiyar mempunyai kekuatan mendasar dari hukum penerapan dalam jual beli. Dan spesifikasi dari nash diatas akan dijelaskan pada Hadits Nabi Saw dibawah :

Malik telah meceritakan kepada kami. Nafi dari Abdullah Ibn, Umar, bahwa Rasulullah saw pernah bersabda : dan pembeh masih dalam keadan Memilih,masingmasing pihak terhadap tetnannya diperbolehkan memilth selagi behun berpisah, kecuali jual beli secura khiyar ${ }^{35}$

Malik telah menceritakan kepada kami. dari Nati dari Thu Umar, bahwa Rasulullah saw telah bersabda Dua orang yang her transaksi musing-masing pihak, terhadap temannya selagi keduanya belum berpisan kecuali transaksi secara khiyar. ${ }^{36}$

Ibn Umar ra. Meng,atakan bahwa hal yang mereka dengar dari Nabi Saw : Apabila beliau memheli sesuatu yang disukainvct uniuk behau jadikan, maka behau berpisah dari sipenjual, lcdu bedalan sedkit, sesudah itu belaiu kembali lagi. ${ }^{37}$

\footnotetext{
${ }^{32} \mathrm{Ibid}$, h. 50

${ }^{33} \mathrm{Ibid}$, h. 65

${ }^{34}$ Ibid., h.78

${ }^{35}$ Ibid., h.78

${ }^{36}$ Ibid., h. 1323

${ }^{37}$ Ibid
} 
Sufyan telah menceritakan kepad akami, dari Ibn Juraij, dari Nafi'; dari Ibn Umar yang mengatakan : Apabila dua orang melakukan transaksi jual beli masing-masing pihak boleh memilih alam transaksinya itu selagi keduanya belum berpisah, alas transaksi keduanya berdasarkan transaksi khiyar ${ }^{38}$. Al-Bukhari dan Muslim meriwayatkan dari Hakim bin Hazan bahwa Rasulullah bersabda :

Dua orang yang melakukan jual beli boleh melakukan khiyar selama mereka beim berpisah. Jika keduanya benar dan jelus, keduanya diberkala dalam jual beli mereka. Jika mereka nzenvembunyikan dan berdusta (Tuhan) akan memusnahkan keberkahan jual beli mereka." ${ }^{39}$

Ibn Umar ra. Bahwa Nabi saw bersabda : Setiap Dua orang yang melaku-kan jual beli belum sah dintayakan jual belt sebelum mereka berisah, kecuali jual beli khiyar. ${ }^{40}$

Dari padanya pula (Ibn Umar bahwa Nabi Saw bersabda: Jika dua orang melakukan jual beli, nzaka keduanya boleh melakukan khiyar sebelum mereka berpisah dan sebelumnya mereka bersama-sama, atau salah seorang karena khiyar, maka mereka berdua melakukan jual beli dengan cara itu, dengan demikian jual beli menjadi wajib. ${ }^{41}$

Dari Uqbah bin Amir ia berkata : Seorang muslim itu bersaudara orang muslin?, ildak halal bagi seorang tnuslTm nienjual kepada saudaranya barang cacat kecuali ia jelas. ${ }^{42 "}$

Dari Aisyah ra. Bahwa Nabi Saw bersabda :Keluar dengan jaminan" Sabda Nabi Saw : Adapun dua penjual dan pembeli boleh khiyar, selama behtm berpisah atau berkata salah seorangnya kepada lainnya silahkan saudara berkhiyar. ${ }^{43}$ Sabda Nabi Saw.

Bila kamu jual beli, katakanlah : tiada penipuan, kamu boleh khiyar pada barang yang engkau belt selama 3 hari. ${ }^{44}$ Dari nash Al-Qur'an dan Hadits Nabi saw

\footnotetext{
${ }^{38}$ Sayyid Sabiq, Figh Sunnah Juz XII, (Cet. I, Bandung Penerbit : PT Al-Ma'arif, 1987), h. 107

${ }^{39}$ Ibid , h. 108

${ }^{40}$ Ibid., h.109

${ }^{41}$ Ibid

${ }^{42}$ Ibid., h. 12

${ }^{43}$ H. Mohammad Anwar, Ptah Islam, Mu'amalah Mumakahat, Faraid dan Jinayah (Hukum Perdata dan Pidana Islam beserta kaidah-kaidah Hukumnya), (Bandung : Al — Ma'arif, 1988), h. 118

${ }^{44}$ Ibid., h.119
} 
diatas maka penulis megambil kongklusi bahwa proses atau penerapan khiyar dalam jual beli akan menjadiwajib karena untuk menghindari penipuan dan untuk kemaslahatan umat.

\section{B. Pendapat Para Ulama}

Dibawah ini rnerupakan pendpat, Para Ulama tentang khiyar sekaligus dengan dasar pendapat :

Madzhab Syalliyah khiyur majelis itu ada pada tiap-tiap akad yang sudah ntemenulti lima qayid :

a. Berupa akad mu'awadhah, yaitu akad yang di laksanakan dengan penukaran barang oleh kedua belah pihak. Di kecualikan dari akad mu'awadhah adalah akad hibah (pemberian); akad. tanpa ada penukaran barang. Karena dia tidak termasuk akad mu'awadhah, maka tidak ada khiyar padanya sesudah akad. Namun bagi si pemberi hibah boleh mencabut ucapan akad hibahnya sebelum akad atau sesudah akad. Namun bagi si pemberi hibah boleh mencabut ucapan akad hibahnya sebelum akad atau sesudahnya. Juga bagi orang tua terhadap pemberiannya kepada anaknya. Dikecualikan dari akad hibah juga, akad perdamai dengan menurunkan harga (rabat), yaitu akad perdamaian atas sesuatu dengan perjanjian mengurangi sebagainya. Misalnya dia mengadakan akad perdamaian menurunkan harga (rabat), yaitu akad perdamaian atas sesuatu dengan perjanjian mengurangi sebagainya. Misalnya dia mengadakan akad perdamaian atas sesuatu dengan perjanjian mengurangi sebagainya. Misalnya dia mengadakan akad perdamaian dengan jaMi mengurangi beban tanggungannya, maka ada penukaran barang pada akad tersebut. Oleh sebab ilu tak ada aiyar padanya.

b. Akad itu rusak sebab rusak gantinya. Misalnya seseorang menjual sesuatu yang bukan miliknya kepada orang lain. maka salah satu dari dua barang yang ditukarkan yaitu dalam hal ini barang yangdijual adalah rusak, maka sah khiyar pada tiap-tiap akad yang rusak karena rusaknya barang gantinya, maka tidak ada khivar baginya.

c. Penukaran tersebut atau barang, yang tetap (mengikat) pada dua belah pihak atau atas manfaat yang abadi dengan lafal bai'. Yang pertania misalnya alat untuk membeli (uang) 
dan barang yang dijual dari pembeli dan penjual. Yang kedua misalnya seseorang menjual kepada tetangganya yang mempunyai hak meletakkan kayu atas dindingnya maka ini adalah bai' manfaat abadi. Dikecualikan dari persoalan diatas ialah akad syirkah dan qirhad. Karena kedua-duanya adalah meru-pakan akad jaiz (boleh mengurngkan akad) bagi salah satu dari dua belah pihak yang melakukan akad.

d. Penukaran tersebut tidak bersifat mekasa. Dikecualikan dari ini akad syulah karena pemilikan dalam syulah sifatnya adalah memaksa, maka tidak ada khiyar baginya. Namun sebagian ulama menyatakan ada khiyar pada akad syurah bagi syafi'i (yang punya hak membei leba dulu), dalam arti dia punya hak khiyar dalam mengembalikan barang yang is mil iki dengan syu ah atau tidak mengembalikan.

e. Penukaran tersebut tidak diberlakukan karena kemurahan, seperti akad hiwalah dan qismah, karena disitu tidak tampak akad bai'.

Dengan batasan ini menjadi mudah untuk menetapkan pelbagai macam akad yang ada khiyar majelis padanya. Dengan demikian pula semua akad mu'awadhah uamg sudah memenuhi syarat-syarat tertentu tersebut bisa mengakibatkan gugur/hialang) karena dua hal :

a. Ada kata-kata yang menunjukkan dengan jelas, bahwa kedua belah pihak telah samasama melangsungkan akad (jual beli). Adapun jika tidak ada kata-kata yang jelas tentang pembatalah khiyar.

b. Penjual dan penmbeli, badannya telah berpisah dari majelis. Sewaktu-waktu salah satu dari mereka meninggalkan majelis dan pergi maka batallah khiyarnya. Yang dimaksud berpisah ialah yang sudah dianggap berisah oleh adat istiadat mereka. Disyaratkan perpisahan itu karena adanya paksaan maka khiyar itu tetap berlaku (tidak gugur). Lama waktu khiyar majelis itu tidak dibatasi. Apabila kedua belah pihak tetap pada tempatnya untuk beberapa hari maka tidaklah hilang hak khtar mereka. Dan apabila salah satu dari mereka meninggal atau gila maka khiyar itu pindah pada ahli warisnya

Menurut Ulama Syafi'iyah khiyar syarat itu ada kalanya bagi penjual dan pembeli, adakalanya bagi dalam satud ari mereka ataubagi orang ketiga. Barang siapa yang telah ditetapkan (syaratkan) baginya hak khiyar, maka dia penjual, pembeli, kedua-duanya 
maupun orang ketiga. Maka tidak sah mensyaratkan hak khiyar pada seseorang kemudian akad diurungkan orang lain menurut kaul mu'tamad. Apabila seseorang mensya-ratkan hak khiyar kepada orang ketiga, maka dia gugur hak khiyarnya kecuali, jia orang ketiga tadi meninggal dunia pada saat khiyar masih berlaku.

Kalau salah satu dari duda orang yang berakad dalam melakukan akadnya mewakilkan kepada seorang wakil, maka wakil tersebut tidak boleh mensyaratkan khiyar kepada orang lain kecuali apabila telah mendapat izin dari orang mewakilkan. Dan apabila dia mensyaratkan khiyar tanpa mendapat izin dari yang mewakilkan. Dan apabila dia mensyaratkan kitiyor tanpa mendapat izin data yang mewakilkan maka batallab akad (jual beli) nya.

Adapun jika telah mendapat izin dart yang mewakilkan, maka dia boleti mensyaratkan (khiyar) untuk orang yang menghalalkan dan untuk dia scndiri.

Menurut Syarfi'iyah khiyar aib, apabila orang membeli sesuatu, kemudia is menemukan cacat padanya, maka ia berhak mengembalikan, jika cacat itu sudah ada sebelum pembeli menerima mabi', sama juga cacat itu sudah ada sebelum akad jual belt atau sesudahnya, tetapi belum diterima si pembeli. Adapun jika cacat itu terjadi sesudah barang disterima, maka apabila penyebab cacat itu sudah lama, maka dia punya hak mengembalikannya juga. Dan apabila penyebabnya tidak lama, maka dia tidak punya hak mengembalikan.

Dicium dan dirasakan, seperti madu, samin, buah-buahan dan semacamnya. Mabi'macam ini sah diperjual Mikan dengan cara dilihat, tidak hams dirasakan atau dicium. Maka bilantana pembeli mcnemukan cacat, maka ia punya hak mengembalikan mabi. Mazhab Hambali (Al-Hambaliah)

Menurut Hambaliah Khiyar majelis tetap ada pada dua belah pihak melakukan akad, meski mereka tidak mensyaratkan dan walau sesudah akad (jual belt) sempurna. Maka bagi masingmasing dart mereka mempunyai hak meneruskan akad dan hak mengurungkannya selama mereka berdua masih tetap dalam majelis, meskipun dia mukmin selama satu bulan atau lebih. Kecuali jika mereka berpisah karena dipaksa. Khiyar majelis tetap (ada) pada beberapa hal: 
a. Persoalan dalam hal milik yang sebagian imbalannya dia menyerahkan sebagian imbalanya dia menyerahkan sebagian dart harganya, karena hal ini termasuk akad jual beli. Adapun perseroan di selain itu tidak ada khiyar baginya.

b. Perdamaian denagn harta, baik berupa benda atau uang tunai, karena hal tersebut termasuk akad jual beli juga.

c. Ijrah atas barang seperti rumah dan hewan atau ijrah atas mafaat yang masih dalam tanggungan.

d. Hibah dengan syarat ada ganti.

Semua akad jual beli yang sahnya dengan syarat adanya serah terima.

Menurut ulama Syafi'iyah khiyar ruiyah, tidak sah jual belt barang gaib ketika dilihat kedua orang yang melakukan akad atau salah satunya. Baik mabi' gaib sama sekali majelis akad maupun ada tetapi terahalang oleh sesuatu sehingga tidak terlihat oleh mereka. Sama saja antara mabi' yang disifati dengan sifat yang dapat menjelaskan. Menurut ulama Syafi'iyah, melihat barang itu cukup dengan membau/mencium dan merasakannya bila mabi'termasuk yang jenis yang dapat Dicium dan dirasakan, seperti madu, samin, buah-buahan dan semacamnya. Mabi'macam ini sah diperjual Mikan dengan cara dilihat, tidak hams dirasakan atau dicium. Maka bilantana pembeli mcnemukan cacat, maka ia punya hak mengembalikan mabi . Mazhab Hambali (Al-Hambaliah)

Menurut Hambaliah Khiyar majelis tetap ada pada dua belah pihak melakukan akad, meski mereka tidak mensyaratkan dan walau sesudah akad (jual belt) sempurna. Maka bagi masingmasing dart mereka mempunyai hak meneruskan akad dan hak mengurungkannya selama mereka berdua masih tetap dalam majelis, meskipun dia mukmin selama satu bulan atau lebih. Kecuali jika mereka berpisah karena dipaksa. Khiyar majelis tetap (ada) pada beberapa hal :

a. Persoalan dalam hal milik yang sebagian imbalannya dia menye-rahkan sebagian imbalanya dia menyerahkan sebagian dart harganya, karena hal ini termasuk akad jual beli. Adapun perseroan di selain itu tidak ada khiycir baginya.

b. Perdamaian denagn harta, baik berupa benda atau uang tunai, karena hal tersebut termasuk akad jual beli juga. 
c. Ijrah atas barang seperti rumah dan hewan atau ijrah atas mafaat yang masih dalam tanggungan.

d. Hibah dengan syarat ada ganti.

e. Semua akad jual beli yang sahnya dengan syarat adanya serah terima. Oleh karena sahnya akad ini harus dengan syarat ada serah terima, akad salam dan akad menukarkan barang yang diukur atau ditimbang dengan sesamanya. Tidak ada khiyar pada pembagian secara paksa karena akad itu adlah menentukan hak bukan jual beli sebagaimana tidak ada khiyar dalam majelis. ${ }^{22}$

Syarat meniadakan khiyar ini tidak dapat membatalkan akad, tetapi hanya khiyar saja yang hilang. Hak khiyar menjadi tidak berlaku karena empat perkara :

a. Sebelum akad ; vat beli selesai dengan sempurna, penjual dan pembeli mensyaratkan tidak ada hak khiyar.

b. Penjual dan pembeli tidak memberlakukan khiyar sesudah akad (jual beli) itu selesai dengan sempurna.

c. Menurut adat istiadat penjual dan pembeli sudah berpisah badan dari majelis. Apabila salah satu dari mereka meninggalkan dengan tujuan melangsungkan akad jual beli atau karena ada tujuan lain. Akan tetapi haram berpisah tanpa mendapat ijin dari yang lain dengan tujuan melangsungkan jual beli dan tidak mengurungkannya. Sebagaimana sabda Nabi saw :"Tidak halal bagi salah satu dari dua orang yang melakukan akad jual beli untuk meninggalkan teniannva karena takut perkara yang ukun tetjadi" ( HR. An-Nasai)

d. Salah stu dari penjual atau pembeli telah meninggal dunia. Flak khiyar bagi penjual dan pembeli tidak berlaku lagi karena salah satu dari mereka meninggal dunia, sebab mati adalah perpisahan yang amat besar. Demikian pula hak khiyar mereka tidak berlaku karena salah satunya sakit gila atau sedang pingsan maka tidak hilangkan hak khiyarnya.

Ulama Hambaliah berkata khiyar syarat ${ }^{23}$ itu ada dalam suatu akad sebelum akad tersebut menjadi lazim, seperti jika penjual dan pembeli berpisah dari majelis setelah akad selesai dengan sempurna tanpa syarat. Dan apabila akad itu sudah menjadi lazim maka hilanglah khiyar syarat. 
Menurut ulama Hambilih khiyar aib, kaidah cela yang menyebabkan barang yang diperjualbelikan dapat dikembalikan ialah cacatnya barang seperti binatang yang dikebiri, walaupun dengan cela tersebut nilai barang berkurang menurut kebiasaan pedagang. ${ }^{24}$

Sebagian ul;ama memberi batasan cacat ialah suatu cela yang mana adat kebiasaan menghendaki selamatnya benda yang diperjualbelikan dari cela tersebut.

Menurut ulama Hanabiah khiavarruivah. sah memperjual belikan barang gaib (yang tidak ditempat) dengan dua syarat :

a. Hendaknya benda yang diperjual belikan ( mabi') itu sendiri dari sesuatu yang sah dilakukan terhadap akad salam. Yaitu barang-baranv, yang dapat ditentukan dengan menyebut sitlitnya, seperti barangbarang yang dapat ditakar atau ditimbang. Maka sah memperjual belikan buah gandum yang sama dan tanah dengan gaib.

b. Menyebutkan sifat-sifat yang dapat rnembatasinya, yaitu berapa si fat yang kalau disebut biasanya dapat membedakan nilai barang (harga) dengan kalau tidak tersebut. Yakni sifatsifat yang cukup (disebut) dalam akad salam.

\section{Madzbab Hanali (Al-Hanafiyyah)}

Ulama hanafiyyah berkata : hak khiyar nurjelis tidak berlaku bagi orangorang yang melakukan akad, kacuali dengan beberapa syarat; apabila akad mereka telah selesai dilangsungakan dengan sempurna tanpa mensyaratkan adanya hak khiyar maka akad (jual belt) itu menjadi tetap (mengikat), baik penjual maupun pembeli masih berada ditempat (majelis) maupun sudah berpisah. Sesuatu yang masih menjadi hak bagi mereka yang melakukan akad dalam majelis tanpa syarat hanyalah khiyar kaul (ucapan).

Menurut madzhab Hanaliyyah khiyair syarrit bagi penjual dan pembeli secara bersamasama atau salah astunya dan sahnya untuk orang ketiga.

Apabila salah satu dan dua orang yang melakukan akad penjual dan pembeli mensyaratkan khivar kepada orang lain, maka tidaklah hilang hak khivarnra melainkan dia mempunyai hak khiyar bersama-sama dengan orang lain. Tadi. Apabila orang ketiga (waki) tado melangsungkan akad atau membatalkan dan disetujui orang yang mewakilkan, maka sahnya transaksi itu tanpa ada silang pendapat ulama. Namun apabila orang yang mewakilkan tidak menyetujui. Juga sah penerapan (syarat) khiyar dari wakil. Apabila 
seeorang mewakilkan kepada orang lain untuk membelikan sesuatu barang dengan tanpa diperintah minta syarat khiyar untuknya atau untuk dia sendiri atau untuk orang lain (ketiga) maka sahnya syarat khiyar tersbut. Namun apabila dia menyuruh wakilnya untuk membelikan dengan syarat adanya khiyar untuknya, kemudian wakil menetapkan khiyar untuk dirinya, maka syarat itu tidak sah. Dan apabila wakil membelikan tanpa khiyar sama sekali, maka luluslah jual beli bagi wakil tidak ada bagi yang mewakilkan. Apabila dia menyuruh wakilnya untuk menjualkandengan khiyar, kemudian dijual tanpa khivar maka batallah jual beli tersebut.

Dalam pada itu menurut ulama Hanafiyyah adalah sah syarat khivar pada tiap akad lazim yang mengandung faskh, sama juga lazim (tetap) dart segi salah satu pihak maupun dart dua belah pihak.

Dikecualikan dart akad lazim, washiyat, karena dia bukan akad lazim, sebab oarng yang berwasiat boleh mencabut ucapan wasiatnya selama dia masih hidup, bagi orang yang dowasiati berhak menerima dan menolaknya, maka tiada artinya jia ada khiyar. Seperti . wasiap talah `ariyah (pinjam-rneminjarn) dan wadi'ah (titipan).

Menurut ulama Hafiyyah khiyar aib, adalah sah menyatakan bebas (tidak tanggung jawab) terhadap sesuatu yang ada pada barang yang diperjual belikan dalam setiap keadaaan. Baik syarat itu umum ataupun khusus. Dan sama juga dia mensyaratkan bebas dirinya, yakni dia mensyaratkan bahwa dirinya tidak bertanggung jawab atau sesuatu cacat yang muncul pada barang yang diperjual belikan, atau dia mensyaratkan bebas dart barang yang diperjual belikan tentang keselamatan dart cacat. ${ }^{28}$

Menurut ulama Hafiyyah, khiyar ru'yah, tidak ada memperjual belikan barang gaib yang tidak dapat dilihat oleh dua belah pihak yang melakukan akad baik barang itu ditempat akad maupun tidak. Adalah salt memperjual belikan barang yang gaib kalau ada dua syarat :

a. Barang itu adalah milik penjual sendiri.

b. Hendaknya penjual menjelaskannya dengan sifat-sifat yang dapat moinilangkan keamaran. ${ }^{29}$

Maka sah menjual belikan barang gaib yang benar-henar milik penjual bila dia memberi penjelsan yang dapatmenghilangkan kesamaran. Dan tidak bahaya adanya sedikit samaran, karena dapat hilang dengan khiyar ru'yah sebab sewaktu membeli mabi' atas 
dasar-dasar sifatnya ini, maka dia mempunyai hak khiyar untuk melangsungkan akad atau men gurungkannya ketika is sudah melihat mabi' tanpa disyaratkan. Karena khiyar ru'yah itu tetap tanpa syarat.

Adapun jia seseorang menjual ssesuatu dan tidak menerangkan sifat-sifatnya, padahal mabi' itu tidak terlihat oleh pembeli misalnya mabi' itu ada ditempat akad tetap tertutup, seeperti gandum yang dalam karung/kantong, dan penjual tidak memberi isyarat kearah kantong, maka menurut pendapat yang shahih akad itu fasid (rusak). Dan sebgaimana ulama mengesankan, namun menurut kaul mu'tamad adalah tidak sah.

\section{Madzhab Maliki (Al-Malikiyyah).}

Ulama Malikiyah berkata: tidak khiyar majelis sanra sekali, bahkan khiyar itu terbagi mcnjadi dua bagian :

a. Khiyar syarat, disebut juga khiyur turuni; yaitu hak untuk fnemilih antara melangsungkan adak (jual dan mengurungkannya. Arti inilah yang dimasudkan khiyur scam mutlak menurut kebiasaan (urul) ahli figh.

b. Khiyar Naqishah, juga dinamai khiyar hukmin sebab berlakunya klavar ini ialah adanya cacat pada barang yang dijual atau barang yang dijual itu ternyata milik orang lain. Hadits : "penjual dcm pembei adalah dengan hak khiyar selama keduanva belum berpisah"

Menurut madzhab Maliki menetapkan klayar syarat bagi penjual, pembeli dan untuk orang lain (ketiga), kalau khiarsyarat diberikan kepada orang lain bertiga, maka dialah yang berhak bicara dalam soal mengurungkan akad (jual beli) atau melanjutkannya. Dan tidak ada hak bicara bagi orang menetapkan khiyar syarat.

Seperti halnya hak khiar adalah persetujuan. Barang siapa yang membeli barang dagangan atau menjualnya kepada si fulan dengan janji ada hak khiyar untuk orang lain dalam membatalkan akad atau melangsungkannva. maka tetaplah hak khiyar itu padanya dan ada hak bicara dalam khiyar bagi yang telah mentapkan tadi. Demikian juga jika seseorang rnenguntungkan akad jual beli itu padanya dan tidak ada hak bicara dalam bagi yang telah menetapkan. 
Letak perbedaan antara dun bentuk akad tersebut adalah, bahwa orang yang mensyaratkan hak khiyar- atau persetujuan dari dirinya sendiri. Sedang orang yang menggantungkan riciisyawarah dari orang lain, dia berarti masih memberi hak bicara kepada dirinya .sendiri disamping memerangi pendapatnya sendiri, tidak tergantung orang lain tadi.

Apabila orang yang melakukan akad mewakilkan kepada orang lain, kemudian di wakil membelikannya barang dagangan dengan syarat khiyar, maka orany, yang mewakilkanpun mempunyai hak khiar bersamanya (wakil), dan dilaksanakan akad orang pertama dari mereka berdua, kecuali jiaka barang telah diterima oleh orang yang kedua. Dan untuk sahnya khiyar disyaratkan hendaknya si penjual tidak menerima uang lebih dahulu menurut kaul mu'tamad.

Menurut ulama Malikiyah khiyar aib, kaidah atau batasan suatu cacat yang krarenanya barang yang diperjualbelikan dapat dikembalikan ialah cela yang dapat mengurangi atau menurunkan harga barang, seperti tidak patuhnya hewan dantidak tunduk (jinak)nya hewan, atau cela yang dapat mengurangi zatnya benda yang diperjualbelikan seperti hewan yang kebiri, jika hal tersebut menurut adat pendapat mengurangi nilainya, juga cacat yang dapat mengurangi daya kerja seperti hwan yang kena penyakit menular. Ketentuan ini keluar dari apa yang dicenderungi ulama hafiyyah dan Syafi'iyah.

Menurut ulama Malikiyyah khiyar ru'vah, apabila orang menjual baran dagangan yang tidak ada ditempat (gaib) yang belum dilihat oleh pembeli, maka ada dua keadaan :

a. Mabi' tidak terlihat oleh pandangan pembeli, tetapi sebenamya ada ditempat akad, misalnya gandum dalam kantong dan gula dalam peti. Dalam hal ini akad jual belt tidak sah sehingga melihat barang dagangan tersebut selagi membukanya tidak mengakibatkan rusak,

b. Barang itu tidak ada ditempat akad, baik ia berada diluar kota atau didalam kota, dan sama juga dia mudah dihadirkan atau tidak. Dalam keadaan demikian sahnya akad jual belt tanpa harus melihat barang.

Atas dasar kedua hal tersebut diatas, sah akad jual belt tanpa melihat barang. Kecuali bila telah ada salah satudari dua hal berikut: 
1. Mensifati barang dengan yang dapat menentukan dan menjelaskan macam dan jenisnya.

2. Mensyaratkan khiar ru'yah pada barang itu.

Apabila ada orang menjual barang dagangan dengan pasti tanpa denan cara pembeli mehhatnya dan tanpa disifati, baik dari penjual atau dari orang lain, maka jual beli ini adalah rusak. Adapun jika disifati, maka adanya menjadi sah dan ia tidak punya hak khiyar sewaktu melaihatnya, kecuali jika telah ditentukan atau tidak sesuai dengan sifat yang " menjadi dasar akad jual.

Kalau orang, menjual harta dagangan dengan pasti tapa dengan syara pembeli punya hak khiyar dan penjual tidak menyifati barang maka sah akad jua belinya dan pembeli punya hak khivar sewaktu mehhatnya.

Jelasnya, barang diharagia sesuai denga sebagainya yang sudah dilihat, bila barang itu termasuk sesuatu yang ada persamaannya yang ditakar seperti beras, sesuatu yang ditimbang seperti kapuk/ kapas. Sedang barang yang tidak memiliki persamaan yaitu yang tidak ditakar atau ditimbang maka (dalam jual beli) tidak cukup hanya dengan melihat sebagiannya Baja.

\section{KONTEKS KHIYAR DALAM JUAL BELI}

\section{A. Obyek Penerapan Khiyar dalam Jual Beli}

Pada dasarnya. Islam menganut prinsip kebebasan terikat, yang kebebasan berdasarkan keadilan, undang-undang agama, dan etika. Didlam pengaturan sirkulasi atau perdagangan terdapat norma, etika agama, dan perikemanusiaan yang menjadi landasan pokok bagi pasar Islam yang bersih.

Diantara norma itu adalah:

1. Mengatakan larangan memperdagangkan barang-barang yang diharamkan.

2. Bersikap amanah dan jujur.

3. Menegakkan _ keadilan dan men gharamkan bunga.

4. Menerapkan kasih saying dan mengharamkan monopoli.

5. Menegakkan toleransi dan persaudaraan.

6. Berpegang pada prinsip bahwa perdagangan adalah bekal menuju akhirat. 
Dari ketentuan-ketentuan terse-but yang merupakan gads kebijakan dalam Islam yang harus ditegakkan dalam setiap transaksi jual belt, karena pada masa sekarang, ini sulit untuk ditemui adanya suatu keterbukaan antara penjual dan pembeli. Konotasi perdagangan bagi para pedagang adalah berupaya meraup keuntungan yang sebanyak-banyaknya, tanpa memperhatikan hak-hak pembeli sebagai salah satu kemaslahatan yang sama-sama harus ditegakkan. berapa banyak pembeli merasa diatitikan alas barang-barang yang dibelinya karena tidak adanya keterbukaan dari pedagang dalam artian tidak merupakan apa sesunggultnya yang menjadi ketetapan syarrat dalam bermu'amalah khususnya jual belt, sehingga melalaikan hal-hal tersebut diatas yang pada akhirnva dalam pelaksanaan jual beli itu bukanlah sesuatu kemaslahatan yang diperolch akan tetapi sebaiknya yaitu kemudharatan.

Adanya khiyar dalam Islam pada jual beli merupakan suatu hal yang baik sekali bagi masyarakat dalarn pelaksanaan mu'amalah. Sikap berhati-hati dalam membeli perlu bagi konsumen, sehingga terhindar dari mendaspatkan barang yang tidak dikehendaki adanya kesempatan memilih untuk melangsungkan atau mebatalkan akad jual belt akan terhindar dari penyesalan bagi pihak pembeli rnaupun penjual. Khiyar akan membuat akad jual beli berlangsung menurut prinsip Islam yaitu, suka sama suka.

Oleh karena khiyar ini sebagai alternatif kemungkinan dalam membendung akan adanya saling tidak percaya antara penjual atau pembeli dan bahkan akan membawa pada permusuhan, maka perlu adanya ketentuan-ketentuan tentang obyek barang-barang dagangan yang memungkinkan ada khiyar apabila dikehendaki oleh kedua belah pihak (penjual dan pembeli). Karena dalam dunia perdangangan pada umumnya barang-barang yang diperjual belikan dipajang ditempat terbuka dengan tujuan agar lebih menarik minat bagi konsumen di samping lebi muda untuk mengalinya dan juga mengetahui kualitasnya. Namun pada kenyataannya tidak semua barang-barang dagangan yang ada dapat dijamin kualitasnya secara lgansung. Untuk itulah dalam kondisi yang demikian penerapan khiyar betul-betul dapat digunakan menurut obyeknya. Misalnya isi telur, barang-barang kimia dalam kaleng dan sebgainya yang kesemuanya hanya bisa dilihat isinya pada waktu dipergunakannya.

Disamping beberapa contoh barang-barang sebagai obyek yang memungkinkan untuk berlakunya khiyar oleh penulis masih banyak lagi sistgem perdangangan yang harus betul-betul 
diperlukan khiyar padanya mengingat berlangsungnya kemaslahatan bersama dalam mebina kerukunan dan keharmonisan dalam bermu'amalah sesuai denan tujuan syari'at. Seperti pada pembeli secara ijon yang yang kebanyakan terjadi pada barang-barang palawija dan didalam tanah seperti umbi-umbian, kacangkacangan atau bebarapa macam komoditi sayur-mayur, yang secara umum biasanya oleh pedangan diperjual belikan menurut luasnya tanah perkebunan yan ada tanaman dimaksud.

Apabila pada kenyataannya barang-barang yang dibeli hanya dengan memprediksi awal akan hasilnya menurut luasnya hektaran perkebunan sesuai dengan harga yang diberikan itu akan berlangsung secra baik dan lancer, namun sebaiknya apabila pada awal prediksi bertentangan dengan kenyataan maka disitulah akan timbul saling sengketa antara penjual maupun pembeli. Pada kondisi semcam inilah khiyar betulbetul sangq berperan yang tentunya terlebih dahulu harus adan-ya ikrar dari kedua belah pihak baik oleh pedangan maupun pembeli.

Hadits Nabi saw Riwayat Muslim : Bersumber dari Ibn Umar dari Rasulullah saw beliau bersabda apabila dua orang mengadakan akad jual beli, maka masing-masing boleh khiyar selagi belum berisah. Sedangkan mereka berkumpul, atau salah seorang dari mereka mempersalahkan yang lain untuk khiyar kemudian mereka mengadakan akad sesuatu denan khiyar tersebut, maka jual beli jadi, dan apabila mereka berpisahsemntara tidak ada seorangpun yang meninggalkan jual beli tetap melaksanakan khiyar-khiyar, maka harus jadi.

Dengan mengacu pada haidts nabi Saw tersebut diatas bahwa kebolehan untuk berkhiyar pada pelaksanaan jual beli sangat dianjurkan. Apapula pada situasi seperti sekarang ini dimana baiasanya penjual dalam memnjajakan barang daganuannya sebagai suatu kemtlakan yang haws laku terjual tanpa melihat resiko yang dialami oleh pembeli karena tujuannya hanya ingin meraup keuntungan yang sebanyak-banyaknya tanpa melihat apakah dia sebaga pedagang muslim, nasrani ataupun yang beragama budha. Nilainilai kemanusiaan tida dipikirkannya lagi a[pabila adanya saling tolong menolong antara sesama manusia. Karena perdagangan merupakan salah satu sendi yang diperlukan oleh umat manusia dalam memenuhi kebutuhannya, dalam menjalani serta mempertahankan kehidupannya dimuka bumi ini. 
Kalau sikap-sikap tersebut diatas dapat dikembanv,kan oleh manusia khususnya dalam pelaksanaan transaksi jual beli, maka akan terbinalah suatu keterangan dan kedamaian hidup diantara sesama manusia karena dengan saling adanya sikap yang demikian para konsumen harga yang ditetapkan oleh penjual.

Mengingat bahwa khiyar ini adlah sebagai satu ketetapan syari'at yang dianjurkan dalam bermu'amalah maka seticlak-tidaknya baai pedanaan muslim khususnya agar mampu rnerealisasikannya dalam praktek perdangan yang ada karena dengan demikian ia telah mampu untuk melaskanakan nilainilai etika dalam bermulamalah yaitu adanya kejujuran dan keterbukaan.

\section{B. Beberapa Khiyar dalam Jual Beli}

Pada hakekatnya kehidupan manusia di dinia ini meliputi dua aspek yaitu material dan spiritual. Aspek material didasarkan atas hubungan sesama, sedangkan aspek spiritual didasarkan atas aspek peribadatan. Aspek material menghendaki agar manusia memperoleh makanan, minuman dan pakaian. Sedang aspek spiritual menghendaki agar manusia mendidik dirinya, membersihkan hatinya dan mendekatkan diri kepada tuhannya denan melakukan peribadatan kepada-Nya dan menaati perintah-Nya.

Mengingat bahwa aspek material merupakan kaedah yang luas bagi perannya nfsu syahwat, gejolak persaingan danperlombaan mengumpulkan harta sebanyak-banyaknya yan kesemuanya itu bahkan sering menggelincirkan manusia dari njilai-nilai keutamaan, menyerahkan kemurnian jiwa dan menjauhkannya dari rahmat Allah serta keridhaannya, maka syari'at Islam memberi petunjuk tentang tata cara dalam berjual beli yang daspat memelihara manusia dari ketergelinciran.

Kemudian Islam juga mendorong dan menganjurkan manusia untuk melakukan jual beli atau melaksanakan perniagaan sebagai upaya untuk memperoleh rezeki, dengan merumuskan tatakrama yang harus diperhatikan dalam pelaksanaan mu'amalah yang ada kenyataannya dianggap sebagai pijakan.

Bagi pemenuhan kebutuhan dan kepentingan hidup manusia, melalui cara-cara yang dapat menyelamatkan manusia dari penipuan, pemalsuan, penyesalan serta hal-hal lain 
yang bisa mengotori diri dan menauhkannya dari aspek kerohanian dalam rangka mendekatkan diri kepada Allah Swt.

Adanya hak khiyar dalam pelaksanaan jual beli mrupakan suatu alternatif untuk menggiring manusia agar tidak melakukan pemalsuan dan penipuan yang pada kenyataannya sering ipraktekkan demi untuk mendapatkan keuntungan yang banyak dari pembeoian, padahal dalam ajaran Islam aspek keuntungan bukanlah sebagai hal prioritas yang ditumakan, tapi masih ada hal-hal lain lagi yang harus diketahui oleh para pedangan, bahwa didalam jual beli itu mengandung unsure ibadah karena adanya aspek tolong menolong dalam pemenuhan kehidupan manusia. Dapat dibayangkan pada suatu tempat jika tidak seorangpun ada pedangan yang menjual kebutuhan-kebutuhan yang diperlukan oleh orang banyak, maka dapat dipastikan aktifitas kehidupan manusia tidak akan terlaksana dengan baik.

Tentang kebolehan khiyar dipegang oleh jumhur fugaha dan tentang masa klayar mereka membolehkannva.

Oleh imam -Malik dikatakan pada dasarnya tidak ada batasan tertentu. melainkan ditentukan berdasarkan besar kecilnya keperluan dengan memadang kepada macammacamnya barang. Dengan demikian, masa tersebut berbeda-beda menurut perbedaan menurut barang yang dijual, is mengatakan seperti satu atau dua hari dalam memilih baju, satu minggu atau lima hari dalam memilih hamba perempuan, dan sebulan atau disekitar itu dalam memilih rumah. Secara ringkas, Imam Malik tidak membolehkan masa yang panjang yang berisi didalamnya kelebihan dalam memilih barang yangd ijual.

Oleh Imam Syafi'I dan Abu Hanifah berpedapat bahwa masa khiyaritu tiga hari tidak boleh lebih dari itu, Imam Ahmad, Abu Yusuf dan Muhammad bin Al-Hasanah berpendapat bahwa khiyar dibolehkan hingga masa yang disyaratkan.

Tentang penaggungan barang yang dijual selama masa khiyar terdapat perselisihan faham diantara fuqaha.

Imam Malik dan para pengikutnya, Al-Laits dan Al-Auza'I berpendapat bahwa kerusakan barang tersebut menjadi tanggungan penjual, sedang kedudukan pembeli adalah sebagaipenerima titipan, baik hak khiyar untuk keduanva bersama salah satunya. 
Tetapi dalam madzhab Maliki juga diriwavatkan bahwa apabila barang rusak ditangan penjual. maka tanggungan penjual terhadap barang tersebut tidak dipersclisIhkan lagi_tetapi jika rusak ditangan pembeli, maka kedudukannya .sarna seperti gadai dan barang pinjaman. Yakni bahwa barang tersebut jauh dari padanya. maka dia (pembeli) lah yang menanggunya. dan jika syarat klaYatuntuk kedua helah ihak atau untuk penjual.

Imam Abu hanifah berpendapat bahwa jia syarat khiyar untuk keuda belah pihak atau untuk penjual saja, maka tangungannya dari penjual, dan barang yang dijual adalah atas miliknya. Tetapi jika khiyar hanya disyaratkan oleh pembeli maka barang tersebut telah dikeluar dari pemilikam penjual dan tidak masuk ke dalam pemilikan pembeli dan terkatung-katung (tidak jelas kedudukannya) hingga selesainya khiyar. Tetapi diriwayatkan pula dari padanya bahwa pembeli harus memberikan harga menurut dia, hal ini menunjukkan bahwa barang tersebut sudah masuk dalam pemilikan pembeli.

Imam Syafi'I mempunyai dua pendapat salah satunya yang terkenal adalah bahwa tanggungan atas pembeli siapapun yang mempunya khiyar.

Akan halnya fuciaha yang meletakkan tanggungan atas pembuat syarat khiyar jika sala satu mensyaratkannyamsedang pihak lainnya tidak, maka mereka beralasan jika penjual itu yang membuat syarat, maka khiyar baginya adalah untuk mempertahankan barang pada pemiliknya. Sedang apabila pembeli saja mensyaratkannya berarti penjual telah menjauhkan dan memisahkan barang tersebut hams masuk dalam pemilikan pembeh_ jika pembeli saja yang mensyaratkan.

Demikian dari beberapa criteria khitur yang ditetapkan oleh apra ulama yang semuanya bertujuan untuk melindungi manusia dari keburukan-keburukan dalam melangsungkan jual beli, sesuai tuntunan syariat yang menetapkan adanya hak khiyar itu dalam rangka keselamatan dan kerukunan serta keharmonisan hubungan antara sesama manusia. Biasanya seseorang terlanjur membeli barang, tapa mempertimbangkan terlebih darhulu dan biasanya hanya tertarik sesaat oleh reklami atau adanya surprise dari penjual, andaikan hak khiyar itu tidak ada, tentu akan menimbulkan penesalan bagi salah satu pihak dan menjurus kepada pertentangan, dendam, dengki 
dan kerahan. Padahal prinsip jual beli harus saling ridha meridhai antara sesamanya, sebagai mana diajarkan melalui haditsnya.

Dari Hakim bin Hizam ra dari Nabi Saw beliau hersabda penjual adan pembeli botch berkhiyar selama keduanya belum herpisah maka apahila keduanya jujuzdan terhuka, maka diberkahi dalam jual belinya dan apabila bohong dan menyinzan alb di hapuslah berkah jual belinya.

Dua orang yang melakukan jual beli boleh melakukan khiyar selama mereka belum berpisah. Jika keduanya benar dan jelas, keduanya diberkahi dalam jual beli mereka. Jika mereka menyembunyikan dan berdusta (Tuhan) akan memusnahkan keberkahan jual beli mereka,

Hadits diatas memberi pemahaman, bahwa tiap-tiap pihak dari kedua pihak ini mempunyai hak antara melanjutkan atau membatalkan selama keduanya belum berpisah secara fisik. Dalam katian pengertian berpisah direlai sesuai dengan situasi dan kondisinya. Dirumah yang kecil, dihitung sejak berpindahnya salah seorang dari tempat duduknya bangkit dan pergibersama-sama maka pengertian berpisah belum ada pendapat yang dianggap rajih, bahwa yang dimaksud berpisah disesuaikan dengan adat kebiasaan setempat.

Demikian darisejumlah ketentuan-ketentuan sebagai criteria dalam pelaksanaan khiyar yang untuk situasi perdagangan masa kini mungkin kurang disikapi oleh para pedagang, karena akan berpendapat kurang menguntungkan, namun perlu adanya satu kesadaran bahwa jika syari'at menetapkan suatu yang diperuntukan oleh manusia tentu punya konotasi sebagai adanya kemaslahatan bersama yang diinginkan oleh semua pihak.

C. Analisa terhadap Penerapan Khiyar

Dari uraian-uraian diatas yang telah ada terlebih dahulu dapat dilihat khiyar dengan segala aspek yang berkenaan denan penerapannya, yan dari situ dapat dipahami daslam bermu'amalah khususnya pada transaksi jual beli harus betul-betul menerapkan adanya

saling menguntungkan antara kedua belah pihak baik antara penjual atau pembelt. Penjual akan mendapat keuntungan dari barang dagangannya sebaiknya pun pembeli9 akan memiliki barang sebagai kebutuhan untuk dimanfaatkan. 
Islam mengajarkan agar usaha orang Islam adalah suaha yang baik dan halal, is memelihara yang makruf dan harga-harga yang normal, tidak mengeksplorasi kebutuhan orang dan menaikkan harga berlipat ganda atau bahkan menvembunyikan cacat barang dagangan atau tidak memcrlukan untuk adanva Lehiasaan berpikir kepada konsumen untuk melaksanakan jual beli maka apbila seorang pedagan telah berbuat demikian maka sesungguhnya ia telah berbuat lalim kepada masyarakat untuk itu ia harus ditindak dan dipaksa menyesuaikan dengan batas-batas keadilan dan kcnormalan tentang kualitas barang serta kualifikasi harga yang sesuai. Semua mu'amalah dalam Islam akan sempurna, biasa mu'amalah itu bersilat jelas. terang jauh dart praktekpraktek penipuan, pemalsuan dan menutupi cacat dan aib. Jika Allah menghapus berkah jual beli, yang dilakukan dengan menyembunyikan cacat dan pemalsuan terhadap pembeli maka syarrat tidak bisa membiarkan mu'amalah itu berlaku meluluskannya, tetapi memberi hak kepada pembeli untuk mengembalikan barang sudah dibelinya dan menuntut penjual untuk mengganti barang yang telah ia jua. ${ }^{45}$

Dalam pelaksanaan jual beli yang padanya terdapat hak khiyar ada beberapa persoalan yang harus dikemukakan:

1. Khiyar Svarat, ulama filth sepakat menyatakan bahwa khiyar syarat ini di bolehkan demi memelihara hakhak pembeli dari unsure penipuan yang mungkin terjadi dari pihak penjual menurut mereka khiyar syarat harga berlaku dalam transaksi yang bersilat mengikat kedua belah pihak (seperti jual belt sewa-menyewa, perserikatan dagang dan rahn) untuk transaksiyang sifatnya tidak mengikat kedua belah pihak, scperti hibah. pinjam meminjam, perwakilan dan wasian. Khiyar seperti ini tidak berlaku. Demikian juga halnya dalam akad jual belt pesanan (Al-Bat' AsSalam) dan Syarf (Valuta Asing). Khiyar syarat juga tidak berlaku, sekalioun kedua akad tersebut bersifat mengikat kedua belah pihak yang berakad karena dalam jual belt pesanan disyartkan pihak pembeli menyerahkan seluruh harga barang ketika akad disetujui dan dalam akad syarf disyaratkan dapat dikuasai (diterima) masing-masing pihak setelah perseetujuan dicapk dalam akad. Sedangkan khiyar syarat menetukan bahwa baik barang maupun nilai/harga barang baru dapat dikuasai secara hukum setelah tenggang waktu khiyar yang disepakati itu sesuai. 
2. Khiyar at-Ta'yin, khiyar seperti ini menurut ulama mazhab Hanafi adalah boleh adalannya, produk sejenis yang berbeda kualitas sangat banyak dan tidak diketahui secara pasti oleh pembeli. Sehingga ia memerlukan bantuan seorang ahli. Khiyar ini ditujukan agar pembeli tidak tertipu dan sesuai dengan kebutuhannya. Ulama mazdhab Hanafi yang membolehkan khiyar ta'yin mengemukakan tiga syarat untuk sahnya khiyar ini yaitu :

a. Pilihan dilakukan terhadap barang sejenis yang berbeda kualitas dan sifatnya.

b. Barang itu berbeda sifat dan lainnya

c. Tenggang waktu untuk khiyar ta'yin menurut ulama madzhab, hanya berlaku dalam transaksi yang bersifat pemindahan hak milik yang berupa, materi dan mengikat bagi kedua belah pihak, seperti jual beli.

3. Khiyar al-Aib (Cacat), menurut kesepakatan ulama fiqh, khiyar aib ini berlaku sejak diketahuinya, cacat pada barang yang diperjual belikan dan dapat diwarisi oleh ahli waris pemilik khiyari. Adapun cacat yang menyebabkan adanyanya hak khiyar, menurut ulama madzhab Hanafi dan Hambah, adalah seluruh unsure yang merusak obyek jual beli tersebut dan mengurangi nilai menurut tradisi para pedagang. Sedangkan menurut ualam madzhab Maliki dan Syafi'I adalah seluruh cacat yang menyebabkan nilai barang itu berkurang atau hilang unsure yang diinginkan dari padanya.

Menurut pada ahli fiqh, syarat-syarat berlakunya khiyar aib setelah, diketahui ada cacat pada barang itu adalah :

a. Cacat itu dieketahui sebelum atau setelah akad tetapi belum sera terima barang dalam harga, ataucacat arang itu merupakan cacat lama.

b. Pembeli tidak mengetahui bahwa pada barang itu cacat ketika akad berlangsung.

c. Ketika akad berlangsung, pemilik barang (penjual) tidak mensyaratkan bahwa apabila ada cacat tidak bisa dikembalikan.

d. Cacat itu tidak hilang sampai dilakukan pembatalan akad, Pengembalian barang yang ada cacatnya berdasarkan khiyar aib tersebut bisa terhalang karena hal-hal sebagai berikut : 
- Pemilik khiyar rela dengan cacat yang ada pada barang. baik kerelaan itu ditujukan secara jelas melalui ungkapan maupun melalui tindakan.

- Hak khiyar itu digugurkan oleh yang memilikinya, baik melalui ungkapan yang jelas maupun tindakan.

- Benda yang menjadi obyek transaksi itu hilang atau muncul cacat baru disebabkan perbuatan pemolik hak khiyar atau barng itu telah berubah total ditangannya.

- Terjadi penambahan materi barang itu ditangan pemilik hak khiyar seperti, apabila obyek jual belinya berupa tanah dan tanah itu telah dibangun atau telah ditanami berbagai jenis pohon atau apabila obyek jual beli ilu adalah hew an. maka anak hewan itu telah lahir ditangan pemilik khiyar akan tetapi apabila penambahan itu bersifat alami (seperti susu kambing yang menjual obyek jual beli atau buabbuallan dari pohon yang diperjualbelikan) maka tidal: menghalangi hak khiyar.

4. Khiyar ar-Ru'yah, jumhur ulama mengemukakan beberapa syarat berlakunya khiyar ar-Ru'yah sebagai berikut :

a. Obyek yang dibeli tidak dilihat pembeli ketika akad berlangsung.

b. Obyek akad itu berupa materi (seperti: tanah, rumah dan kenclaraan).

c. Akad itu sendiri mempunyai alternatif untuk dibatalkan seperti jual belt dan sewa-menyewa.

Menurut jumhur ulama apabila ketika syarat ini tidak dipenuhi, maka khiyar ru'yah tidak berlaku. Apabila akad itu diakibatkan berdasarkan khiyar ru'yah maka menurut jumhur ulama pembatalan harus memiliki syarat-syarat berikut :

- Hak khiyar masih berlaku bagi pembeli.

- Pembatalan itu tidak berakibat merugikan penjual (seperti pembatan hanya dilakukan pada sebagian obyek yang diperjual belikan).

- Pembatan itu diketahui oleh pihak penjual.

Menurut jumhur ulama, khiyar ru'yah akan berakhir apabila: 
- Membeli menunjukkan kerelaannya melangstingkannya jual beli, baik pernyataan atau tindakan.

- Obyek yang diperjual belikan hilang atau terjadi hambatan cacat baik oleh kedua belah pihak yang berakad orang lain, maupun oleh sebab yang alami.

- Terjadinya penambahan materi

- Obyek setelah dikuasai pembeli. seperti tanah yang dibeli itu telah dibangun rumah atau kambing yang dibeli itu telah beranak akan tetapi apabila penambahan itu, menyatu dengan obyek jual beli (seperti : susu kambing yang dibeli atau pepohonan yang dibeli itu berbuah), maka khiyar ru'yah bagi p embeli tidak gugur.

- Orang yang memiliki hak khiyar itu meninggal dunia baik sebelum melihat obyek yang dibeli maupun sesudah dilihat, tetapi belu ada pernyataan kepastian membeli dari padanya.

Menurut ulama madzhab Hanafi dan Hambali khiyar ru'yah tidak bias diwariskan kepada ahli waris. Tetapi menurut ulama madzhab Maliki khiyar tersebut bisa diwariskan, dan karenanya hak khiyar berlangsung gugur dengan wafatnya pemilik haktersebut. Tetapi diserahkan kepada ahli Ivarsinya untuk dilanjutkan satelah melihat obyek yang diperjualbelikan atau dibatalkan.

5. Khiyar Majelis, tentang khiyar majelis ini terdapat beberapa pendapat ulama mengenai keabsahannya.

Ulama mazhab Syafi'i dan Hambali berpendapat beberapa bahwa masing-masing pihak yang melakukan akad berhak mempunyai khilyar majelis, selama mereka masih dalam majelis akad sekalipun akad telah sah dengan adanya ijab (orang kapan jual_dari penjual), dan qabul (ungkapan beli dari pembeli), selama keudanya masih dalam majelis akad maka masing,-masing pihak berhak untuk melanjutkan atau membatalkan jual beli tersebut, karena akad jual beli ketika itu dianggap masih belum mengikat, akan tetapi, apabila setelah ijab dan qabul masingmasing pihak tidak menggunakan hak hiyarnya dan mereka berpisah badan/tempat, maka jual beli itu dengan sendirinya menjadi mengikat, kecuali apabila masingmasing pihak sepakat menyatakan bahwa keduanya masih berhak dalam jangka waktu tiga hari untuk mebatalkan jual beli tersebut. 
Menurut ulama madzhab Hanafi dan Maliki, suatu akad suah sempurna dengan ada ijab qabul. Alasan mereka adalah suatu akad sudah dianggap sah apabila masing masing pihak telah menunjukkan kerelaannva.

Orientasi pemikiran para ulama dimasa lampau dalam pencrapan khij.ar setidak-ticiaknya dapat menjadi toal ukur serta rujuakannya harus kita pegangi dalam bermua'amalah apapula pada kondisi sekarang ini khususnya pada pelaksanaan transaksi jual beli, sebagai masarakat muslin. pedagan muslim setidak-tidaknya nilainilai yang ada dalam syari'at Islam hendaknya dapat kita terapkan ditengah-tengah kehidupan masyarakt luas disana terdaspat bermacam-macam etnis maupun golongan, ataupun agama. Namun dalam Islam sebagai syari'at yang diterangkan secara lengkap dari Allah swt yang didalamnya terdapat segenap aturan-aturan yang dianjurkan kepada umatnya agar dilaksanakan. Antara lain dari aturan-aturan itu berkenaan dengan perdagangan atau perniagaan antara lain :

\section{Benar}

Benar adalah ruh keimanan. cirri utama orang mukmin, bahkan cini Nabi tanpa kenbearan, agama tidak akan tegak dan tidak akan stabil. Sebaliknya, bohond dan berdusta merupakan bagian dari pada sikap orang munafik. Bencana besar didalam pasar saat ini adalah mulusnya tindakan dusta dan batil, misalnya berbohong dalam mempromosikan barang dan menetapkan harga. Oleh sebabsalah situ karakter pedagang yang terptenung dan dindhai oleh Allah ialah kebenaran.

Pada zaman sekarang untuk mempromosikan komditi dagangannya, orang menggunakan sarana iklan, dan kenyataan membuktikan pengaruh iklan lebih besear daripada pengaruh keimanan didalam hati manusia.

Pada zaman dahulu, keimanan sangat memepengaruhi perilaku manusia. Keimanan didalam dada seseorang walaupun sebesar biji sawi, Dewasa ini urnat manusia banyak dikelabui oleh iklan yang Karena gencarnya promosi melalui iklan, akhirnya seseorang membeli barang yang sarna sekali tidak dibutuhkannya, bahkan sebenarnya is tidak sanggup membelinya. 


\section{Menepati amanat}

Menepati amanat merupakan moral yang mulia. Maksud amanat adalah mengembalikan hak apa saja kepada pemiliknya, tidak mengambil, tidak mengambil suatu melebihi haknya dan tidak mengurangi hak orang lain. Dalam berdagang dikenal istilah "menjual dan amanat' seperti menjual merabah maksudnya, penjual menjelaskan kualitas dan harga barang dagangan kepada pembeli tanpa melebihlebihkannya.

\section{Ajar}

Selain benar dan memegang amanat, seseorang pedagan harus berlaku jujur, di landasai keinginan agar orang lain mendapatkan kebaikan dan kebahagiaan sebagaimana is menginginkannya dengan cara menjelaskan cacat barang dagangan yang dia ketahui dengan tidak boleh pembeli. Lawan sifat jujur adalah menipu (curang), yaitu mcnonjolkan keunggulan barang tetapi menyembunyikan cacatnya.

Masyarakat umum sering tertipu oleh perlakuan oleh para pedagang seperti ini. Mereka mengira suatu barang itu balk kualitasnva. namun ternyata sebaliknya."

Masalah perdagangan adalah sebagai sesuatu yang taagguly dalam agama Islam. Karena meskipun syari'at tidak menerpakan dengan hukumhukumnya itu sudah berlaku dan berkenan sepanjang adanya manusia karena sebagai suatu kebetulan, seperti perkawinan, perdangan, tolong-menolong, pinjam-meminjam dan lain-lain. Hanya saja didaslam agama melalui syari'tnya yang berhubungan dengan hal-hal tersebut diatas, sehingga akan mebawa manusia untuk lebih mengutamakan kemaslahatan didalam hidupnya. Oleh karean syari'at bertujuan melindungi manusia dari pada keburukankeburukan serta kesenang-wenangan maka dalam perdagangan syari'at menetapkan adanya hak khiyar, karena perdangan meruapkan suatu sendi dalam kehidupan manusia, malalui dengan nya tingkat kebutuhan manusia akan dapat terpenuhi. Untuk itu bagi para pedagang khususnya pedangan muslim dianjurkan untuk memegangprinsip-prinsip yang sesuai dalam ajaran agama dalam mekanisme perdangan pclabagai bagian dari apda upaya untuk melestarikan nilai nilai ajaran islam demi tegaknya ekselamatan kerukunan erta keharmonisand alam hubungan antar manusia. salah satunya dengan mempraktekkan hak khiyur dalam transaksi jual beli. 


\section{PENUTUP}

A. Kesmpulan

Secara sederhana, penerapan khiyar dalam jual belt dapat dikonkritisasi atau diaplikasikan, sebab khiyar mempunyai solusi yang jelas dan yang dipakai oleh ekonom modern sekarang dengan beda istilah atau yang dikenal dengan istilah garansi. Hampir semua produksi barang modern menggunakan istilah khiyar (garansii) untuk menarik perhatian konsumen. dan penerapannya memberikan keuntungan yang berlipat. Khiyar (garansi) sangat jeas dan mempunyai arah yang relevan untuk diterapkan. Di dalamnya terkandung prinsip dasar dan tujuan Islam sebagai agama rahmatan li;alami (pemberi) rahmat kepada seluruh alam).

Konsep khiyar yang dipahami dalam al-Qur'an dan penjabarannya pada Hadits Nabi Saw dan pendapat Ulama merupakan strukturasi ekonomi yang sudah diatur komprehensif dan mempunyai dampak positif dan bahkan khiyar menjadi solusi kongkrit. Dibalik itu ekonomi barat melihat bahwa peningkatan produksi haws dilakukan dengan konsep-konsep riil.

Al-Qur'an mengintrodusir konsep khiyar denga menggunakan istilah-istilah seperti "aladil", "al-haq" dan "Ikhlas". Menurut penulis sebagai analig khirar. dan masingmasing merujuk pada satu arti yakni pihhan bebas dan tanpa ada paksaan (ikhlas). A1-Qur'an mengemukakan secara ter QS hakikat dan kriteria dari khiyar walaupun dalam al-Qur'an tidak secara spesifik menerangkannya.

Khiyar menurut para Ulama adalah salah satu unsure penting dalam melaksanakan jual beli dan untuk menghidnari penyesalan dan membeli sesuatu ataupun menghindari penipuan.

Secara hukum syar'i khiyar dibolehkan, bahkan ada yang mewajibkan untuk menghindari penipuan dan untuk menjaga silatruahmi agar tidak terjadi kesalahpahaman. Karena penekanannya pada nila normative agama yang mempunyai tingkatan tertinggi yakni keikhlasan (saling merekalan).

Konsep ini meruapkan konsep yang baku dalam ajaran Islam tetapi kurangnya aplikasi serta pernerapannya membuat ekonomi Islam terlihat ketinggalan. Akan tetapi ini menjadi tugas untuk melakukan penemuan dan mengobjektivikasi. 
Untuk itu pelaksanaan atau penerapan khiyar perlu dan hams disosialisasikan kepada seluruh umat Islam sebagai objektivikasi agama dan menjaditerobosan baru bagi perkembangan ekonomi khususnya ekonomi Islam.

B. Implikasi Penelitian

Untuk melengkapi penelitian ini dikemukakan implikasi penelitian untuk diiadikan bahan penelitian lanjutan atau bahan pegangan dalam pengalaman nilainilai. normative syari'at Islam sebagai berikut :

1. Penelusuran ayat-ayat yang memakai kata ataupun yang mempunyai relevansi dengan penerapan khiyar atau kata-kata yang mempunyai makna dan arti yang sama ataupun dapat dianalogikan. Penelitian ini mengungkap realitas yang kongkirt dimasyarakat serta ditinjau dari apske Qur'ani, Hadits Nabi Saw dan sebagainya dengan melakukan strukturasi secara mendalam.

2. Penelitian tentang berbagai hal yang diterangkan dalam al-Qur'an Hadits nabi Saw dan pendapat para Ualam atau ahli fiqh mengenai penerapan khiyar dalam jual beli tetap relevan bahkan menjadi stimultan dari masa ke masa. Hasil penelitian in dapat mengungkap tetnang penerapan khiyar yang diingin syari'at Islam. Semoga hasil penelitian ini dapat dijadikan sebagai pegangan bagi imat Islam umurnnya dan generasi muda ilsam khususnya. 


\section{DAFTAR PUSTAKA}

Al-Qur'until Karim.

Abd Azis, Dahalan, Ensilclopedi Hukum Islam III, Cet. I, Jakarta ; Penerbit : Itjtihar van Hoften, 1996.

Abdullah, Hafid, Kunci Figh Svafi'i, Cet. I, Semarang ; Penerbit : CV. Asy-Syifa', 1992.

Abis As-Sindi, Muhammad, Syekh., MusnadSyafi'i :Juz II, Cet. 11, Banduing; Penerbit: PT Sinar Baru Al-Gesindo, 1996..

Al-Bukhari Muhammad bin Ismail Al-Imam Abu Abdullah, Shahih Bukhari, Juz III Tarjamah Achmad Suranto, Cet. I, Semarang ; Penerbit : CV. Ash-Syifa', 1992.

Al-`Assal Muhammad Ahmad et. All., Sistem Prinsip clan Tujuan Ekonona Islam, Cet. I, Bandung; Penerbit : CV. Pustaka Setia, 1999.

Anwar, Mohamad, H., Figh Islam Mu'amalah, Faraid dan finctyah (Hukum Perdata dan Pidana Islam beserta Kaidahkaidah Hukumnya), Bandung; Penerbit : PT. AlMa'arif, 1988.

--------, Tam Malan Tagrib,Bandung ; Penerbit : PT. AlMa'arif, 1991.

Antis. Bev. Terjemah Swum ,411-Nasai', ('et. 1. Semarang: Penerbit : Asy-Syifa. 1993.. AlImam.. .-1/-Chum Terjemah Mid X oleh Yukub, Cet. I. Semarang: Penerbit : CV. Faizan, 1988.

Az-Zuhaili, Wahbah, al-Figh al-Islam IVO Adilatuhur, Hid IV.. Dar alFikr, Beirut

Chapra. M Umer. Dr., Al-Qur'an 'Wimp( Sistem Moneter rang Add, Al-Qur'-1an Men* S'istem Moneter yang Ada, Yogyakart, Penerbit : PT. Dana Bhakti Prima Yasa, 1997.

DepDikBud.. Kumus Basalt Bahasa Indone,sla, Cet. 11. Jakarta, Penerbit : Balai Puistaka, 1989.

Haroen, Nasrun, MA.. Dr.,H., Figh Mu'amalah, Cet. I, Jakarta; Penerbit: Gaya Media Pratama, $1420 \mathrm{H} / 2000 \mathrm{M}$.

Harahan Sayan Syafri, Akuntansi Islam, Cet. I, Jakarta; Penerbit Burnt Aksara, 1997.

Jacob, Hamzah, Dr., Kode EtikDagang Menurut Islam, Cet. I,Bandunug Penerbit Diponegoro, 1984. 
Manan, M. Abd., Teori dan Praktek Ekonomi Islam, Yogyakart; Penerbit : Bhakti Primayasa, 1997.

Muslim bin Hajjaj. Abu Husen Imam, Shahih Nmuslim, Juz. Terjemahan : KH. Adib Bisri.

Susan Ibnu Majah Juz, II, Indonesia; Maktabah Dahlan t.th.

Siddigi Nejatullah Muhammad, Kegiatan Ekonami Dcdam Islam, Jakarta: Penerbit : Bumi Aksara, 1991.

Syahatah, H usein, Dr., Pokok-pokok Pikiran Akultan,si Islam., Jakarta; Penerbit : Akbar Media Eka Sarana, 2001.

Sen Amartya, Masih Adakah Harapan Bagi Kaunr Miskin Bandung,. PenerbitMizan 1988 ,

Syaltut Mahmud, Islam Agidah dal Siyari 'ah, Terjemahan : Abdurrahman Zain, Cet. I, Jakarta: Penerbit : Putaka Amani 1986.

Zuhri, Mohamad, H. Drs., Dipl. Tafl., Tedemeah Figh Empat Mazhab, Jilid III, Semarang; Penerbit : Asy-Syifa', 1994.

Mustola at.all.. Semarang: Pcnerbil: CV. Av-Svi 1993.:

Naclai Heider Sycd Nawab, Etika dun Hinz( Ekonomi win(, cintesis Cet.: 1, Bandung,: Penerbit : Mizan. 1993.

Naim, Mochtar, Kompendium Ilimpummya -ayat .41-our'anrang Berkaitun cicagcni Ekonomi, Jakarta: Penerbit : CV. Hasanah, 2001.

Qardhawi, Yusuf, Dr., Norma dun Etika Ekonomi Islcuri, Penerjemah, Zainal Arifin,Jakarta; Penerbit: Gema Insani Press. 1977.

Rahardjo M. Dawam. Echlin clan Tran,sformasi Saosial Ekonomi, Cet. I, Yogyakarta, Penerbit : Lembaga Studi Agama dan Filsafat (LSAF), 1999.

Rivai Mob., II4utiara Figh, Jilid II Semaran; Penerbit CV. Wicaksana, 1998.

Rusyd Ibnu, Bidayatul Mujtahid, Terjemah : M.A. Abdurrahman et.all. jilid III, Cet. I, Semarang Penerbit : Asy-Syifa', 1990, 
Sabiq. Sayyid,,T;’’igh Sunnah. Jilid XIII, Cet. I. ,andung; Penerbit : PT..rif, 1987. Jilid Alih Bahasa H. Kaman idin et.all, Cet. H, Bandt: Penerbiut: PT. AlMa'ar, 1988. 